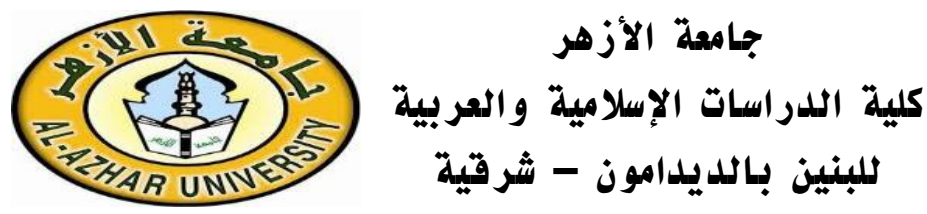

\title{
الوسطية في تربية الأولاد منهم حياة
}

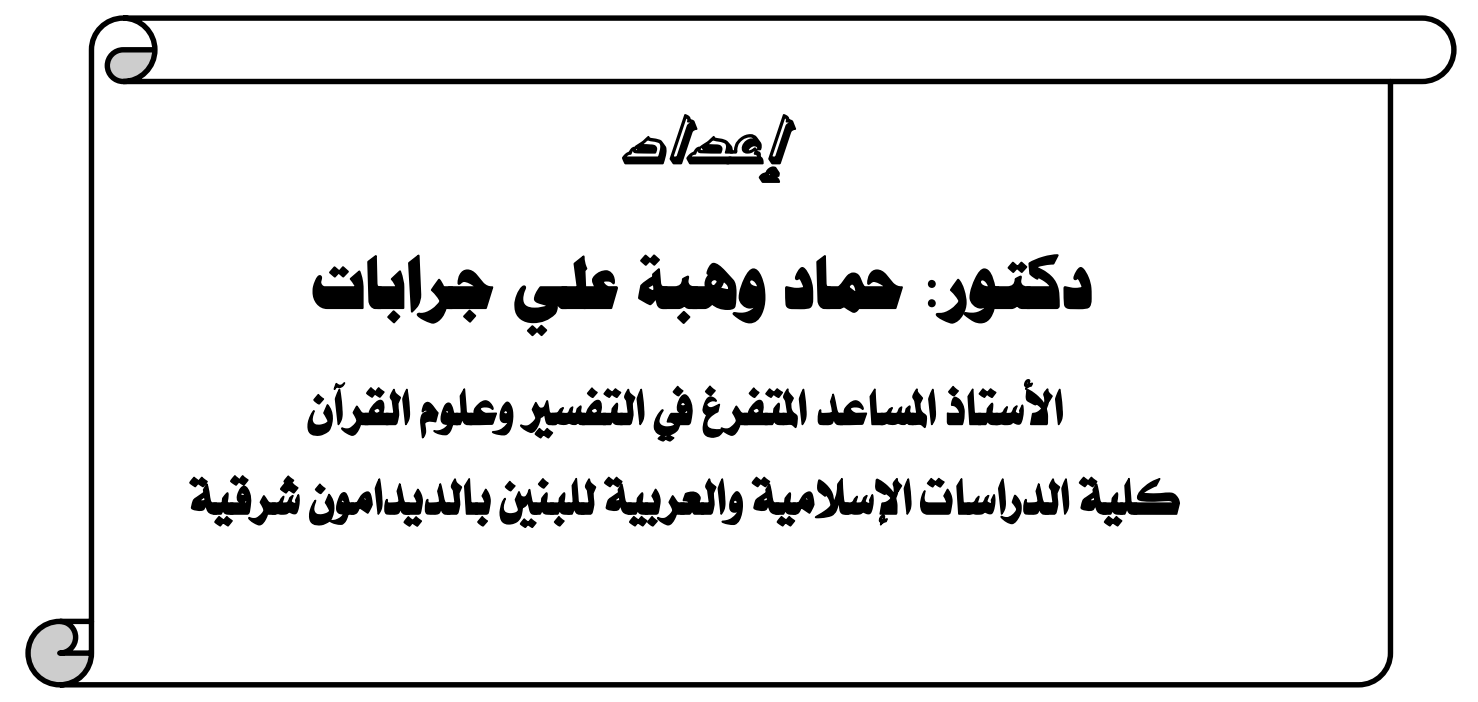

$$
\text { المؤتمر العلمي الدولي الأول }
$$

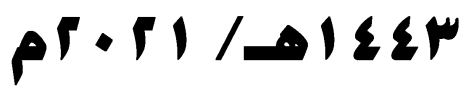


$-11 .-$ 


\section{الوسطية يُ تربية الأولاد منهج حياة \\ حماد وهبة علي جرابات}

قسه: التفسير وعلومهد كلية الدراسات الإسلامية والعربية للبنين

بالديدامون - شرقية المدينة: فاقوس التفية جامعة الأزهر

$$
\text { الدولة: جمهورية مصر العربية المادية }
$$

الأولاد هم فلذات الأكباد، وعاد الظهور، وزينة اللياة الدنيا، وحسبنا قول الحق القربة

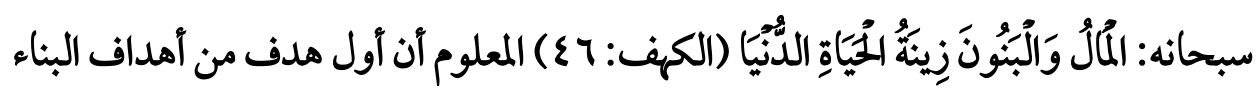
الأسري:: الزواج وإنجاب الذرية، والتطلع إلى تحقيق هذا المدف السامي النبيل بشوق ولهفة أمر فطري في النفس البشرية، فكل إنسان يتطلع إلى تحقيق هذه الرغبة الفطرية. إن الولد بقاء للنوع وامتداد للعمر، والرغبة الإنسانية كشف عنها القرآن الكريم علنه لسان بعض أنبياء اللهصلوات الله عليهم.

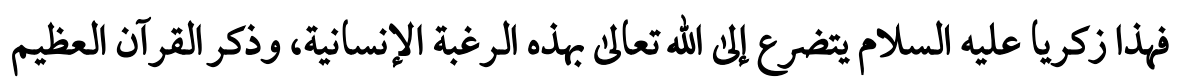

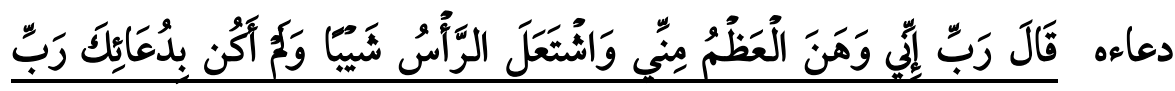

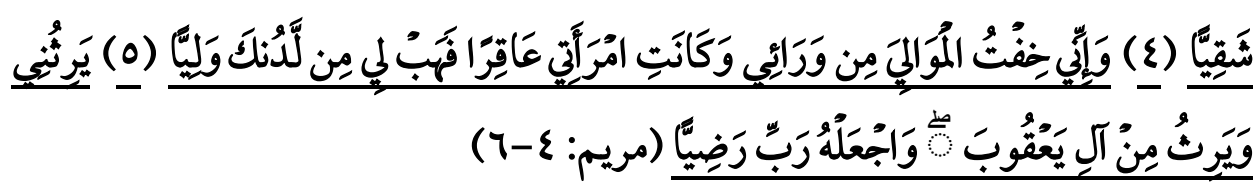

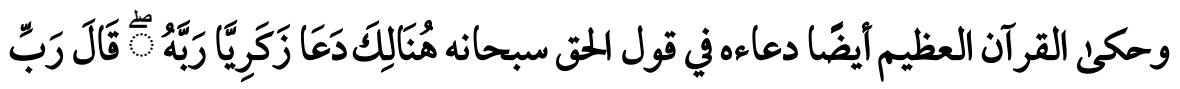

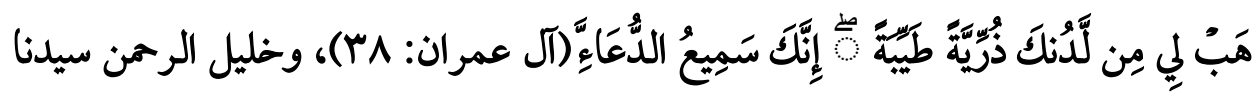

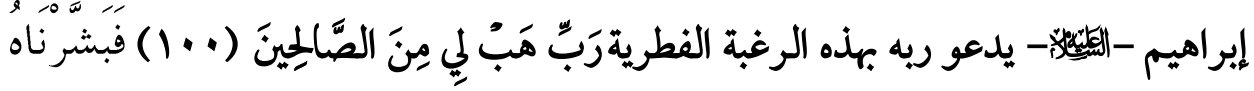

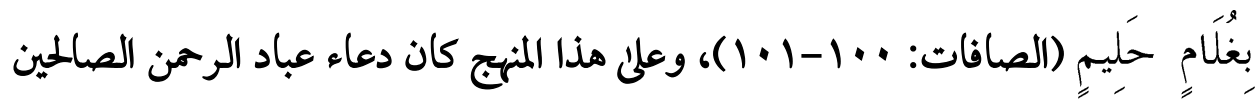

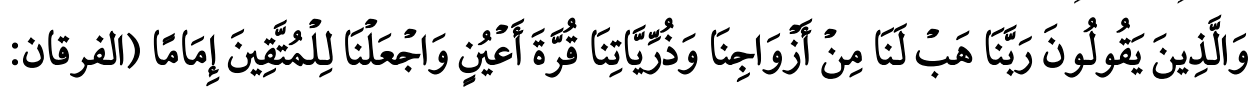

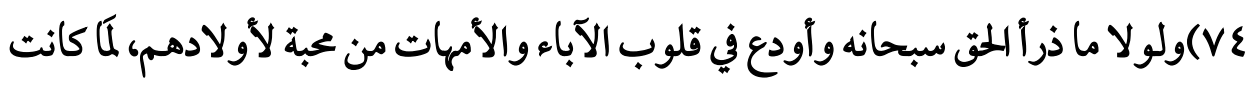

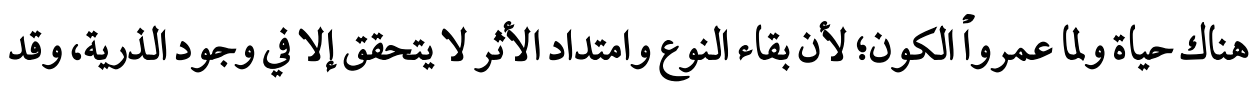
تغنى الشعراء بهذه المحبة الفطرية تجاه أولادهم. 


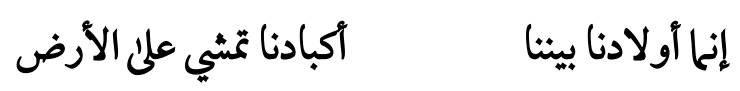

ومن خلال هذه الثوابت اليقينية كان أسمى وأنجح منهج للتربية: هو منهج الوسطية والاعتدال، هذا المنهج يؤهل الناشئة للبناء والنحاء والارتقاء. هذا المنهج -الوسطي- يتعدهم وهم أجنة في بطون أمهاتهم، حتى يشبوا ويتحملوا المسؤلية كاملة في مجتمعهم. هذا المنهج الفذ جعل لهم حقوقا في صغرهم، وحث علئ الالتزام بها بكل دقة، من وجوب رضاعته طفلاً ، واختيار الاسم المناسب الذي يظل معروفًا به مدئ حياته، ووجوب الإنفاق عليه، والمق في التربية والتأديب وفق المنهج الوسطي الذي أبان عنه القرآن

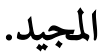

وفي القرآن العظيم نماذج للتربية العملية، التي تأخذ بأيديهم في رفق وآناة وحب. منها: التربية الوسطية على فضائل الأخلاق وسمو ونبل السلوك، ومنها التربية على لئل الآداب الاجتماعية_وخاصة ما يتعلق بالمأكل والمشرب، وأدب الاستئذان والسلوك.

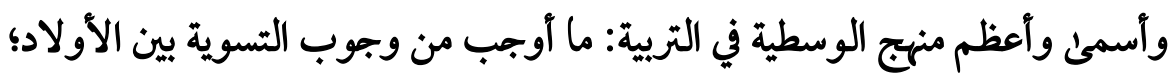
حتى يكونوا أسوياء في سلوكهم. هذا بإيجاز منهج التربية الوسطى لحياة لا عنف فيها ولا شقاق، لحياة وارقة الظلال بكل

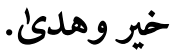
الكلمات المفتاحية: الوسطية - تربية - الأولاد-حياة 


\title{
Moderation in raising children Hmaad Wahba Ali
}

\section{Department of interpretation and sciences of The Quran} Faculty of Islamic studies and Arabic male aldiadamon - sharqia

\author{
city: Faqus
}

AL-Azhar University country: Arab republic of Egypt

Children are our souls, backbones and the adornment of our lives. It is known that one of the first goals of marriage is to have children. The aspiration to achieve this noble goal is innate in human beings. Everyone seeks to achieve this natural desire.

Children are an extension of one's life and a representation of the survival of the human species. As mentioned in the Noble Qur'an by some of the prophets - God's blessings be upon them - here is Zakaria, peace be upon him, praying to God with this human desire. So God answered him and gave him Yahya. And so did our prophet Ibrahim, peace be upon him. And on this approach was the prayer of the righteous servants of the Most Gracious .

If Allah had not deposited in the hearts of fathers and mothers love for their children, there would be no life because the survival of the species can only be achieved by the presence of offspring. Through these constants, the most successful approach to raise children was moderation. This approach gave them rights when they were young. The love of children, breastfeeding them and the choice of good names that will remain with them for life, the right of being spent upon by their father and the right of education and sound moral upbringing in accordance with the moderate approach. And in the Noble Qur'an there are honorable examples of practical upbringing raising children moderately by teaching them virtuous morals and noble attitudes, teaching them the respect of social etiquette 
especially the etiquette of food and drink and the etiquette of asking for permission and the equality in treatment so that they may be just and decent.

Summary of this, we should be moderated and raise our children neither violently nor compassionately to be normal adults and to be functional in the society .

Key words: Moderation- raising- children- life 
إن الأولاد هم فلذات الأكباد، وعاد الظهور، وهم زينة الحياة الدنيا، يقول الله سبحانه

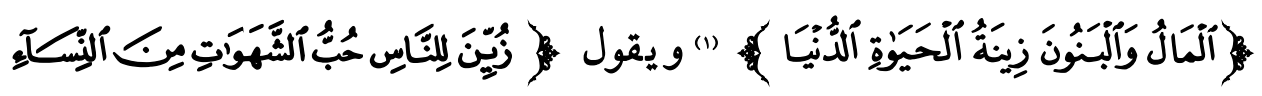

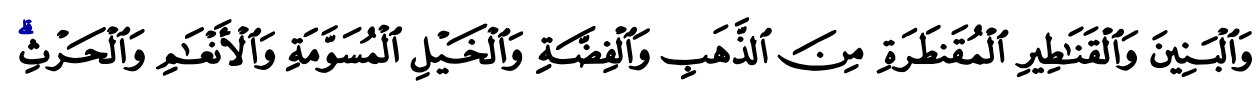

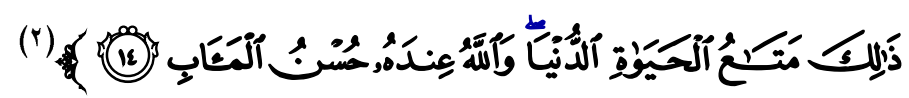

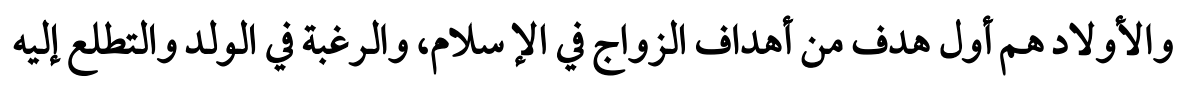

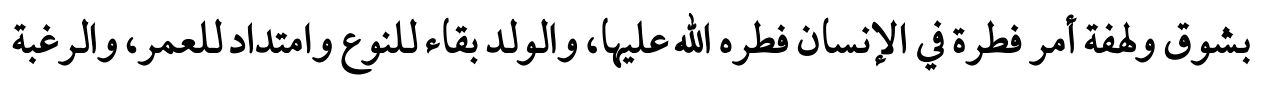

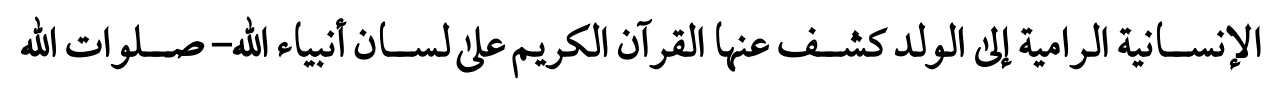

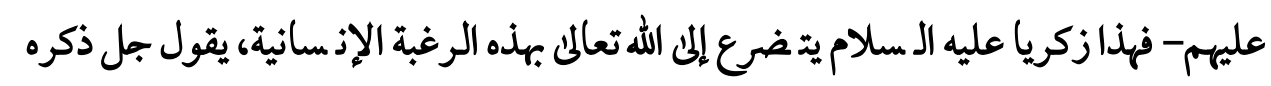

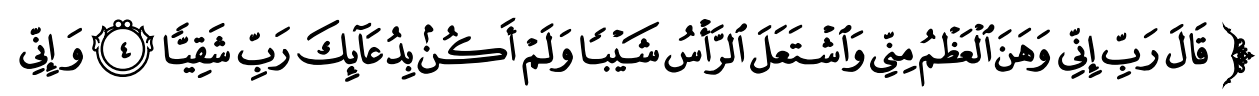

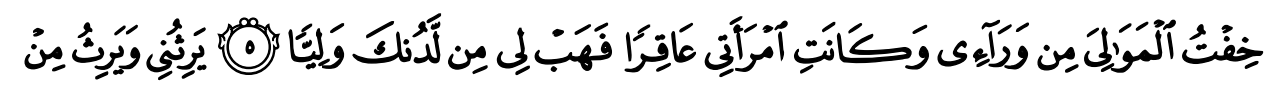

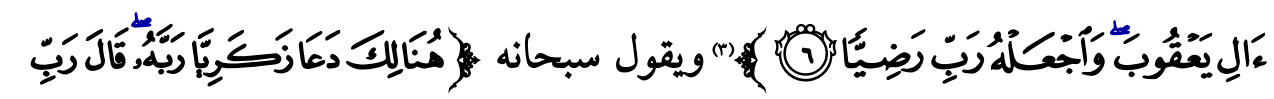

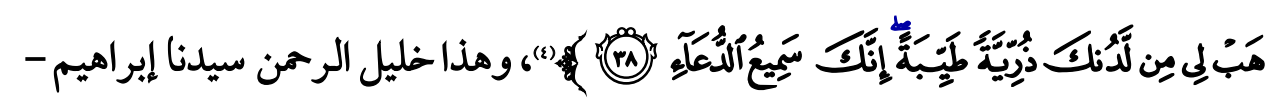

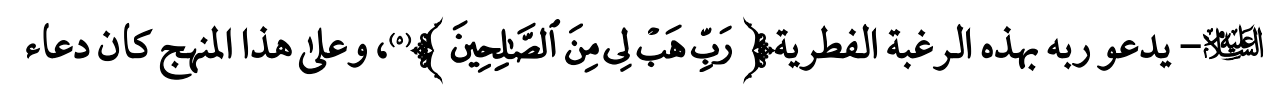

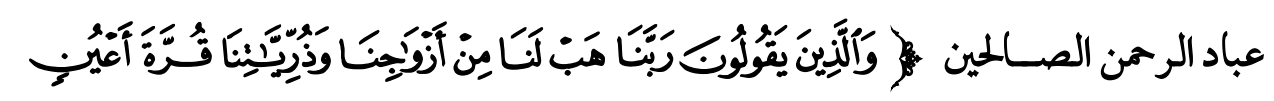

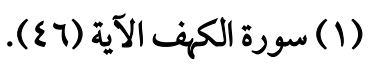

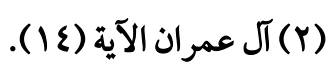

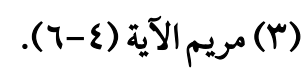

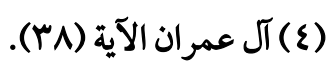

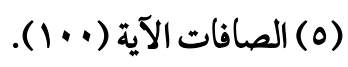




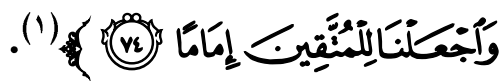

فبقاء النوع وامتداد العمر لا يتحقق إلا في وجود الذرية الصـالحة التي تنهج نهج الآباء الصالحين والمصلحين، ولو لا ما ذرأ المق سبحانه في قلوب الآباء من محبة لأولادهم لما كانت

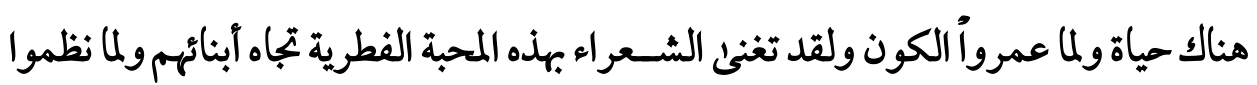

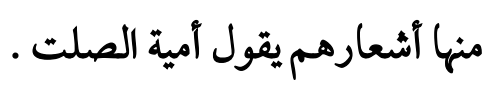

غذوتك مولودًا وعلتك يافقاً تعل بها أجني عليك وتنهل (1)

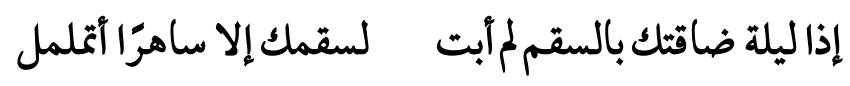

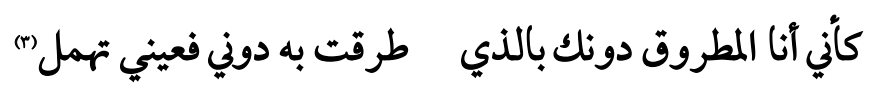
تخاف الردى نفسي عليك وإنها لتعلم آن الموت وقت مؤجل

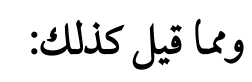

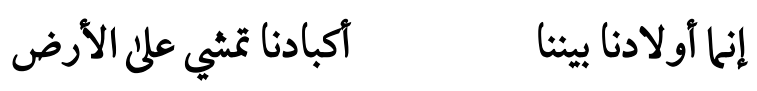

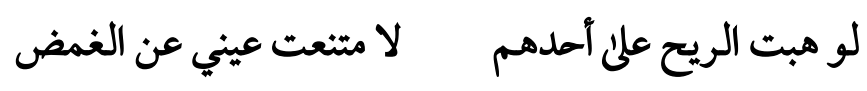

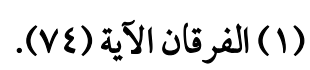

(Y) (Y) علتك أي تكلفت برعايتك، يافعًا أي شابًا. (Y) ت تهل أي تبكي لأجلك. 
تتجلئوسـطية التربية للأولاد في أسـمى مظاهرها في إيجاب حقوق للأولاد في أطوار حياتهم المختلفة. ومن جمال منهج الوسـطية في التربية أن العلاقة بالأولاد تبدأ من نقطة سـابقة على وجودهم تتمثل في حسن اختيار زوجة صالحة تعين علن أمر الدين والدنيا، وتربي الناشئة تربية وسطية صالحة.

أيضًا من جمال منهج الو سطية في التربية تلك الحقوق التي يجب أن تراعلى دون تقصيرًا

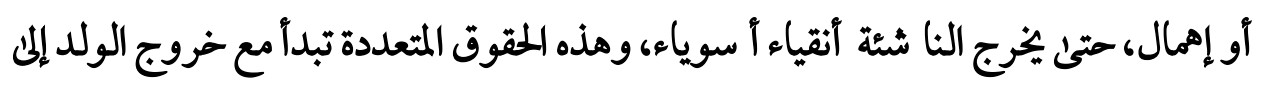
الحياة مع ولادته له حق الرضـاعة، يقول الحقى سـبحانه

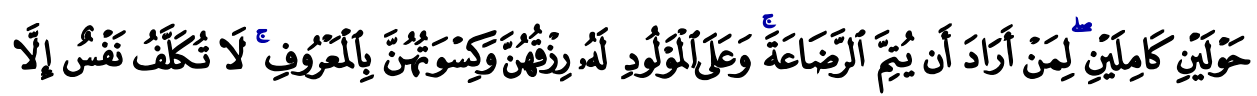

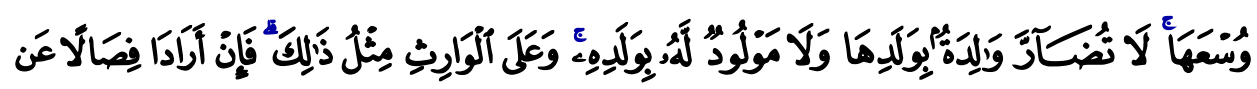

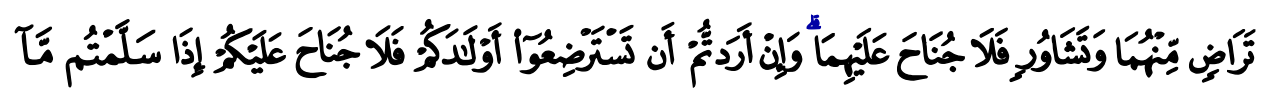

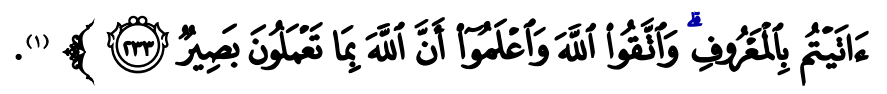
ومن خلال الآية الكريمة نلاحظ ما يأتي:-

1-أحقية الأم في إرضاع صغيرها، وهذا حقه الذي قرره الله تعالى له.

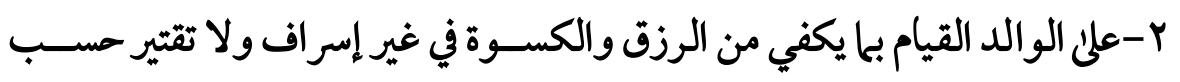

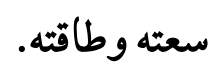
r-لا حرج في آن يعهد بالمولود إلى مرضعة صالحة - وإن أردتم آن تسترضعوا أولادكم

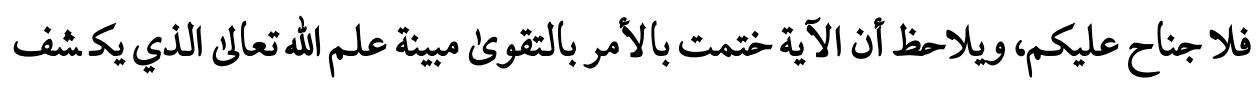

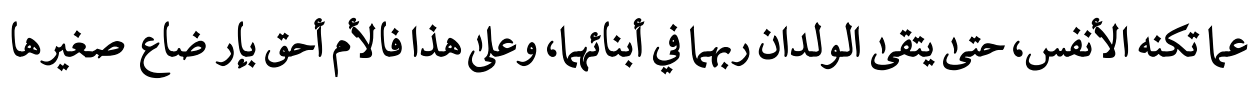


من غيرها حتى يشب على عظيم الحلالال.

"أن لبن الأم يؤثر في جســم الطفل وفي أخلاقه وســجاياه، ولذلك يحتاط في انتقاء

المراضع، ويجتنب استرضاع المريضة والفاسدة الأخلاق والآداب" (1)

والآية الكريمة كما جاء في الفتو حات الإلهية، "خبر بمعنى الأمر و هذا للندب

$$
\text { وللوجوب، فالأول عند استجلماع ثلاثة شروط: }
$$

وللوجوب عند فقد واحد منها، قوله "حولين" هذا التحديد ليس واجبًا، يدل على

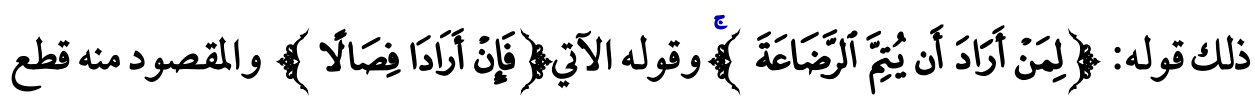
النزاع بين الزوجين في قدر زمن الرضـاعة فقدره بالمولين ليرجعا إليه عند التنازع، وكاملين صـفة مؤكدة؛ لأنه ما يتسـامح فيه، يقال : آقمت عند فلان حولين وإن لم يستكملها، وفائدة هذه الصفة اعتبار الحولين من غير نقص (1).

كميزات لبن الأم: للبن الأم ميزات وخصـائص لا تو جد في غيره من الألبان الآخرى والقرآن المجيد ير شدنا إلى ما فيه صلاح آمورنا في دنيانا وديننا، وقد كشف الطب الحديث عن هذه المميزات، وبين أسرار لبن الأم وأهميته في بناء الطفل، وأهمية هذه الر ضاعة بالنسبة للأم المرضعة آيضًا.

إن لبن الأم يفوق الآلبان الحيوانية والألبان الصناعية من زوايا عديدة منها:ا-أن لبن الرضـيع يحتوي على نسـب متوازنة من غذاء الرضسيع تتلاءم مع احتياجاته

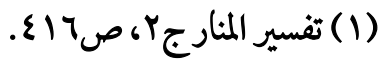

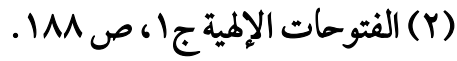


وتلتقي مع احتياجات الرضيع في فترات الرضاعة المختلفة متمشية مع نموه.

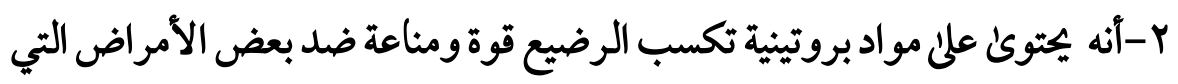

$$
\text { تحصنت منها الأم في الشهور الأولى من عمره. }
$$

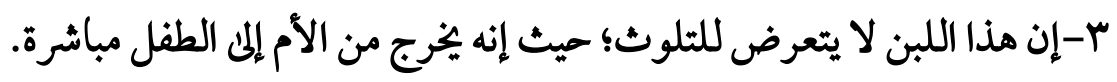

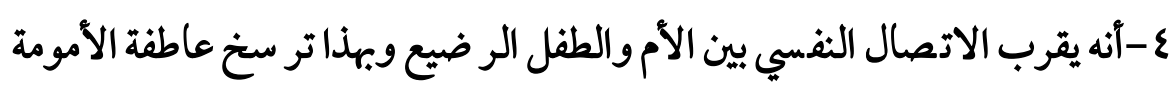
والبنوة بالرباط المتين الصادق الصحيح.

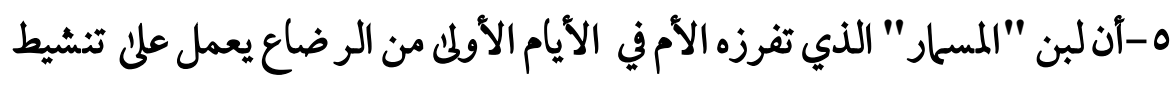
الأمعاء لدى الطفل، فيحدث اللين المناســبـ لدئ الطفل ويسـاعد على عملية الإخراج الطبيعية. 1-أما من ناحية الأم فإن عملية الرضـاع تعجل وتسـتكمل عملية عودة الرحم إلى حجمه وحالته الطبيعية"). ما سبق يتبين بكل جلاء ووضوح أن الرضاعة ها أهيتها الكبرئلحماية الأم والرضيع

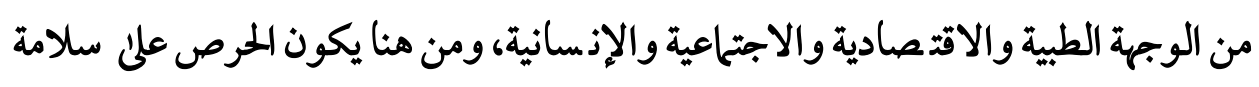
الأم في هذه الفترة حرضًا على الرضيع ذاته، وتوفير المناخ الملائم تمام الملائمة لنموه الطبيعي.

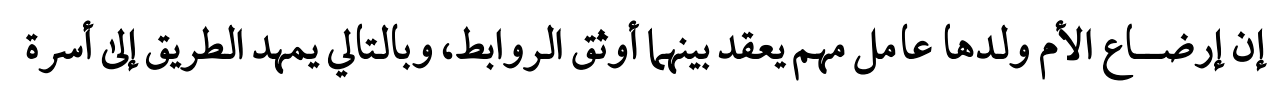
متحاسكة قوية البناء، فالأم بذلك ذات دور خطير. فإذا ما تحملت مسـؤوليتها في رضـاعته ونظافته سـاعدت في إعداده روحيًا وماديًا على ملئ

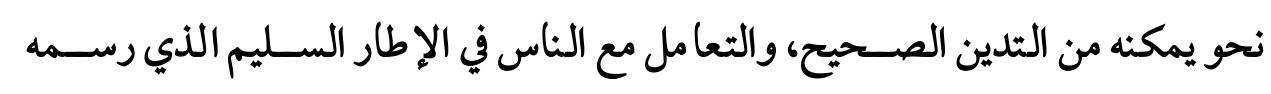
الإسلام. 


\section{تحديل مدة الرضاعة:}

تبين الآية الكريمة أن مدة الرضاعة حلهو لاند كاملان، فتحام الرضـاعة المحقق لغرضها

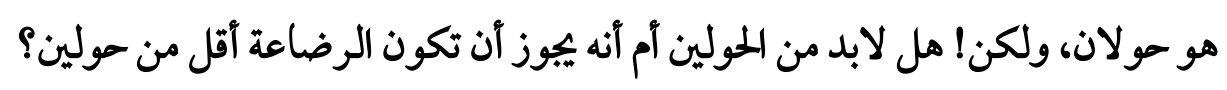

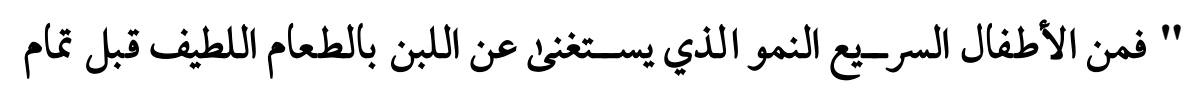

الحولين بعدة أشهر، ومنهم البطيء الذي لا يستغنئ عن ذلك".

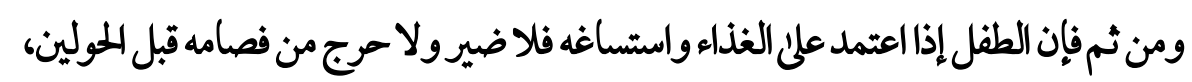
وذلك في حالة ما إذا كان سريع النمو، وهذا الأمر واقع ومشاهد في دنيا الناس.

\section{يقول الإمام ابن كثير:}

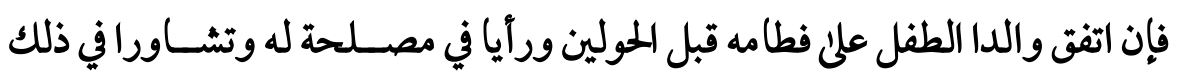

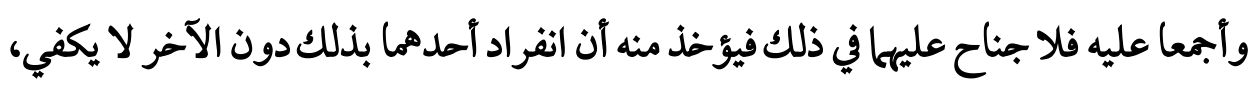
ولا ييوز لواحد منها أن يستبد بذلك من غير مشـاورة الآخر ـ قاله الثوري وغيره، وهذا فيه

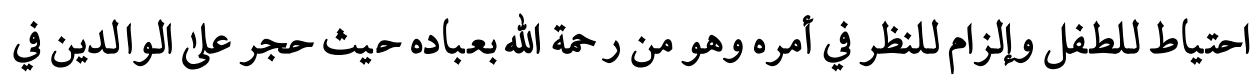
تربية طفلها، وإرشادهما إلى ما يصلحها ويصلحه" (1).

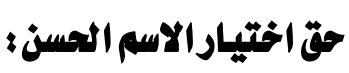

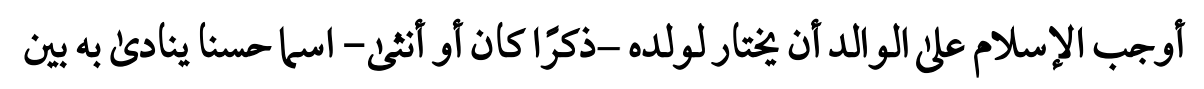

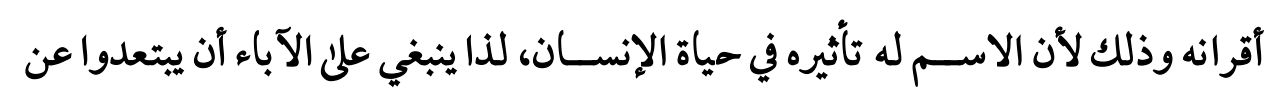
الأسماء التي توحي بالغلظة القا سية أو التدليل المفرط، والناس يوم القيامة ينادون بأ سمائهم وأسـاء آبانهم، ولقد جاءت توجيهات الإسـلام صريحة مؤكدة في اختيار أحسـن الأســاء للأولاد.

\section{من توجيهات النبوة:

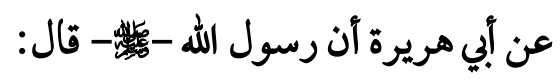


إنكم تدعون يوم القيامة بأسمائكم وأسماء آبائكم فأحسنوا أسمائكم".

ولقد كان من هدية -صــلوات اللهوسـلامه عليه- اختيار أعذب الكلمات وأرقها

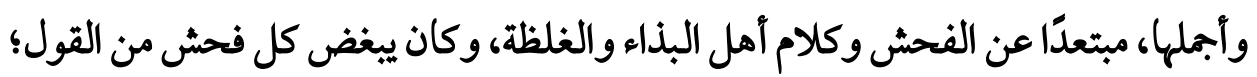
لذا أرشدنا كيف نختار من الأسماء ما يرينا في الدنيا بين الأقران.

\section{يقول الإمام ابذ القيمج}

لما كانت الأسـاء قوالب للمعانيودالة عليه اقتضـت المكمة أن يكون بينها وبينها-أي

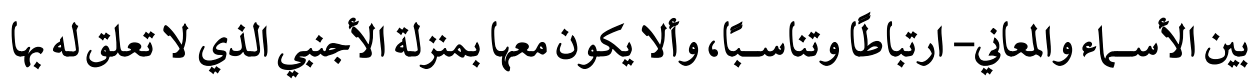

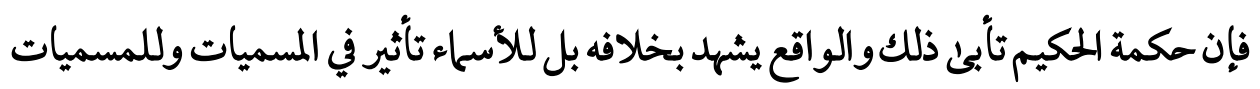
تأثير في أسائها في الحسن والقبح والمفة والثقل، والنظافة والكثافة، كما قيل: وقل إن أبصرت عيناك ذا لقب.... إلا ومعناه إن فكرت في لقبه.

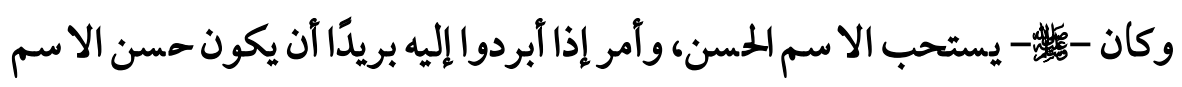

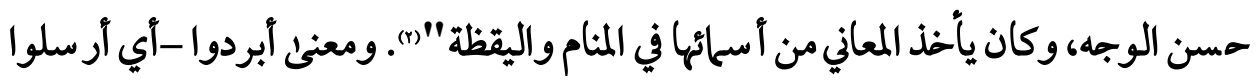

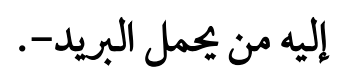

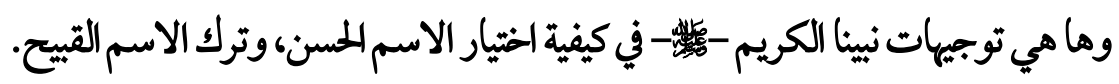

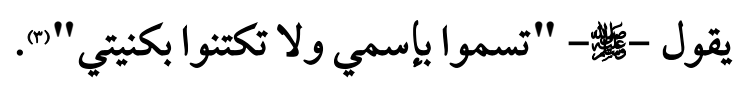

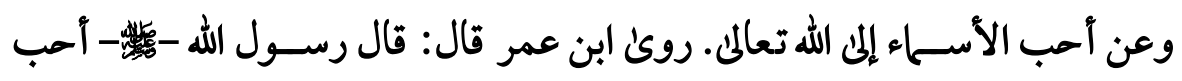
الأسحاء إلى الله عبدالله وعبدالرحمن" (s). وكماعرفنا أن الاسمله تأثير، وحسبنا تصديقًا لهذا ما جاء في الصحيح عن ابن المسيب عن أيي:

$$
\begin{aligned}
& \text { (1) رواه أبو داود في كتاب الأدب ج\&، ص YAV. }
\end{aligned}
$$

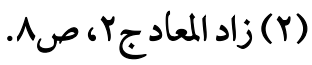

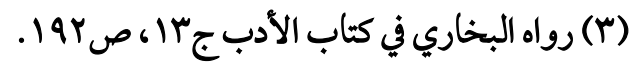

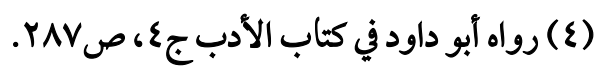


أن أباه جاء إلى النبي ابن المسيب: فماز زالت اللحزونة فينا بعد").

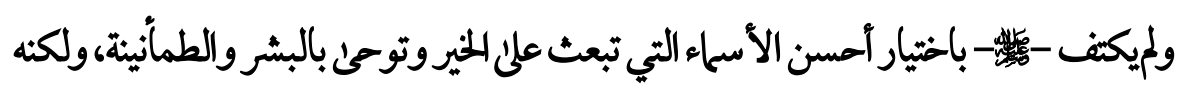

$$
\text { غير كثيرًا من الأسجاء التي توحم بالألموالغلظة ولميبقها أو يقرها. }
$$

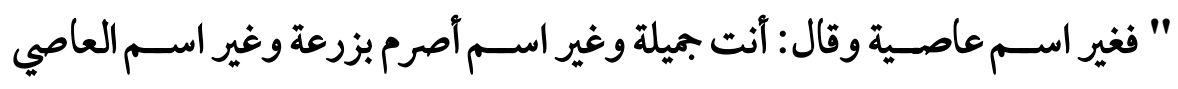

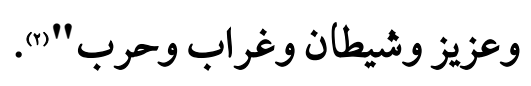

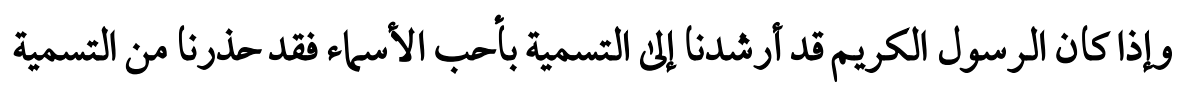

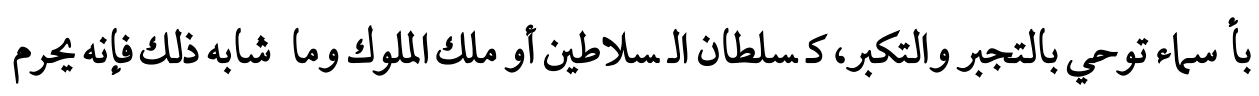
التسمية بهذه الأسماء.

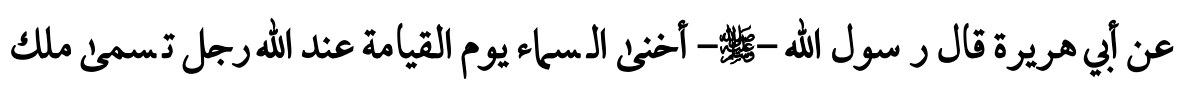
الملوك وفي رواية أخنع السماء عند الله رجل تسمى بملك الأملاك متال. وأخنى: من الحناء وهو الفحش في القول وتحتمل آن يكون من قولمم أخنى عليه الدهر أي أهلكه وأخنع من الحنوع وهو الذل وآخنع أوضع -من الخنوع وهو الذل وأخنع وأوضع -

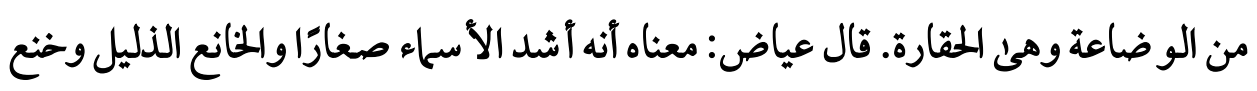

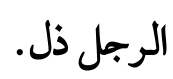

وقال ابن بطال: وإذا كان الا سم أذل الأ سماء كان من تسمىل به أ شد ذلاً، وقد فسر

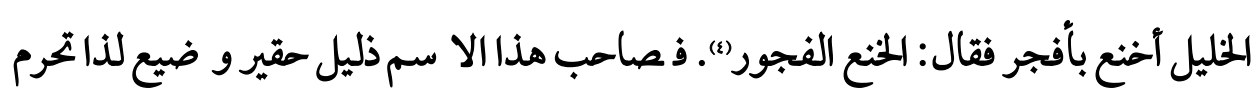
التسمية به.

$$
\begin{aligned}
& \text { (1) (رواه البخاري في كتاب الأدب جrا ، ص } 190 .
\end{aligned}
$$

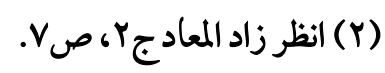

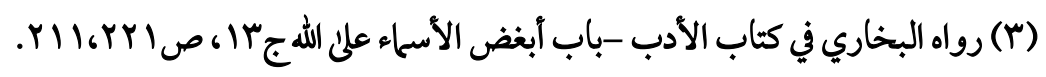

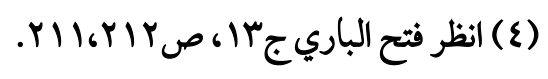




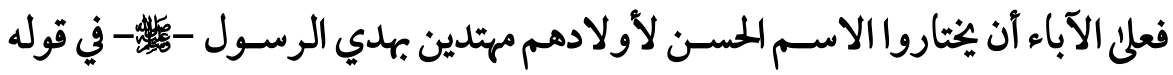

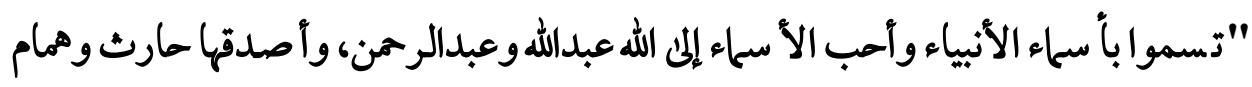

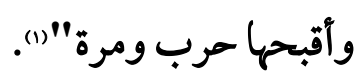

أذكر هذا النور والقلب الحاضر يعتصر حزنا والجبين يندئ خجلاً... لقد ابتليا في العصر

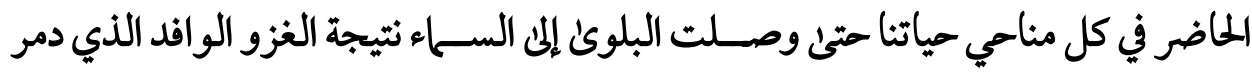

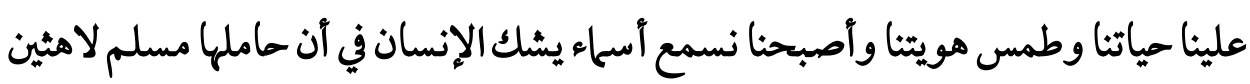

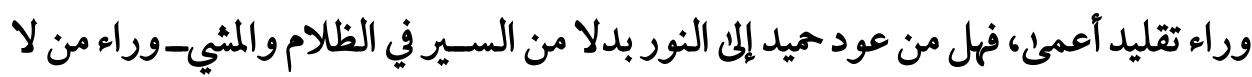
يريد لنا في أدق آمورنا وآعظمها.

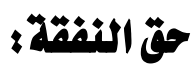

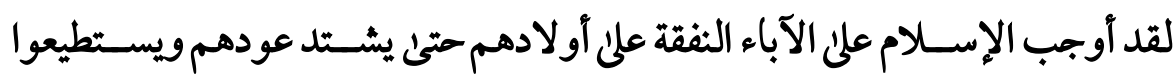

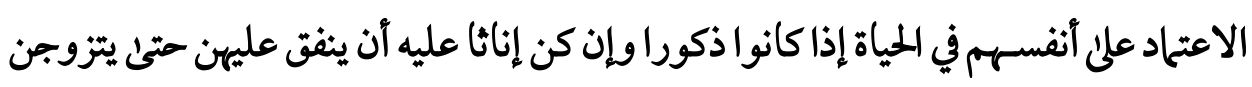

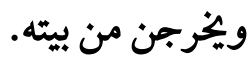

ووجوب النفقة على الأولاد حق قرره الإسـام، وهي نفقة يثاب عليها الآباء ثوابًا

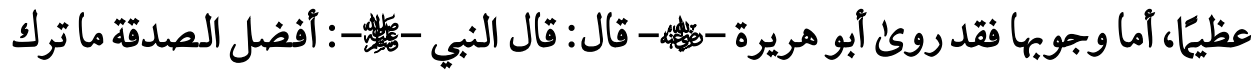
غنى، واليد العليا خير من اليد السفلئ وابدأ بمن تعول (r).

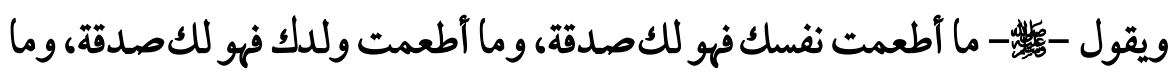
أطعمت زوجتك فهو لك صدقة، وما أطعمت خادمك فهو لكصدقة"(r).

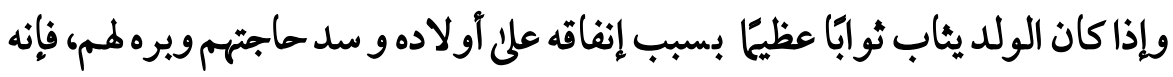

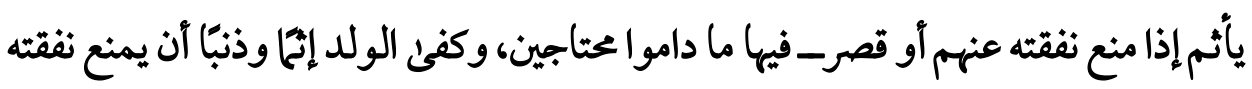

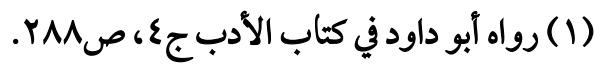

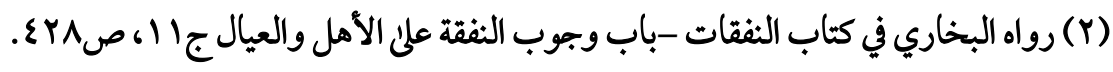

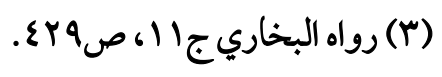




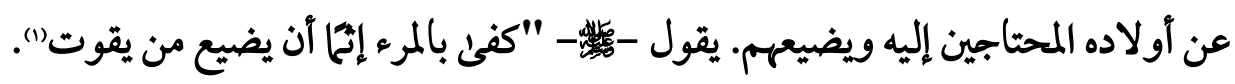

\section{نهوذج للبر الصدة:}

عن صعصعة عم الأحنف قال: دخلت علئ عائشة امر أة معها ابتان لها؛ فأعطتها ثلاث

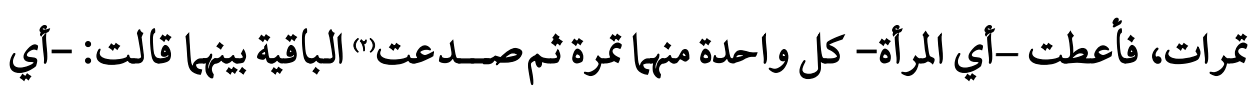

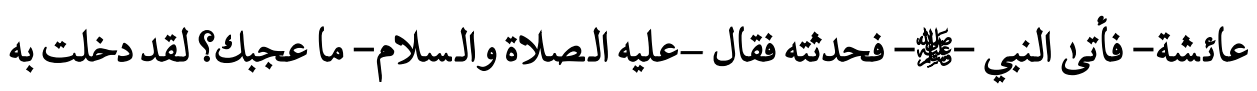
الجنة"

فانظر إلى تلك المرأة الصـالحة التي آثرت ابتتيها، ويجاذا؟ بتمرة واحدة لم تضسعها في فمها لتذوق حلاوتها، أو تستمتع بلذيذ طعمها، ولكن لتشقها نصفين بين ابتتيها.

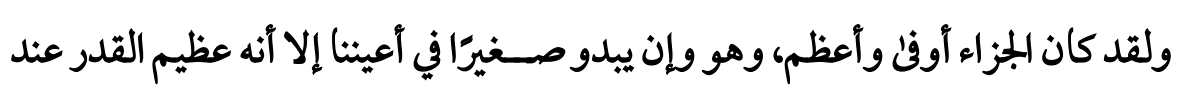

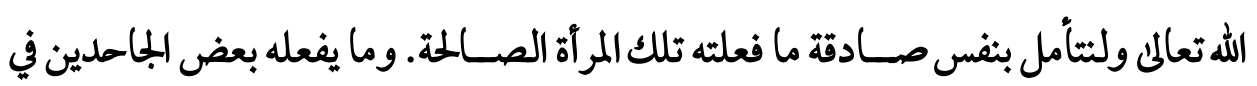

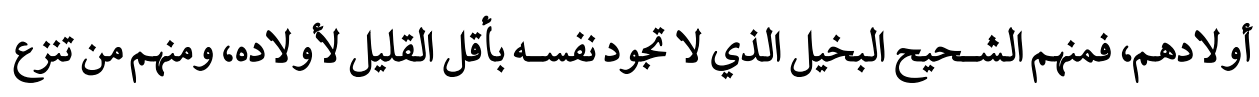

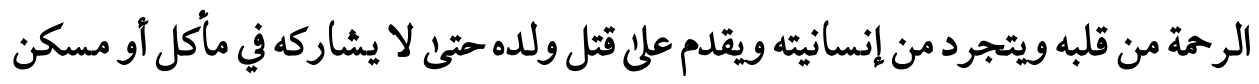
أو ملبس أو أي عرض زائل لا قيمة له.

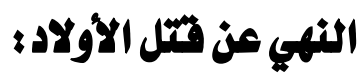

لقد نعى الحق سـبحانه علني أهل الجاهلية. وحكم عليهم بالخسر سان، يقول جل وعز "

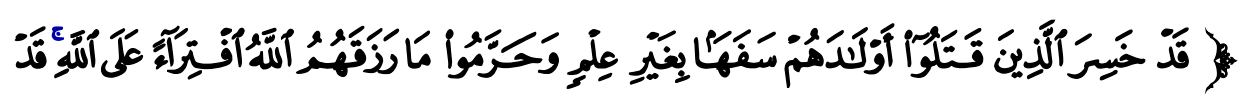

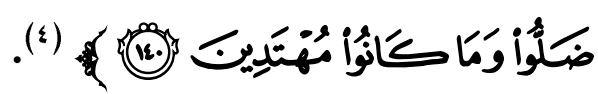

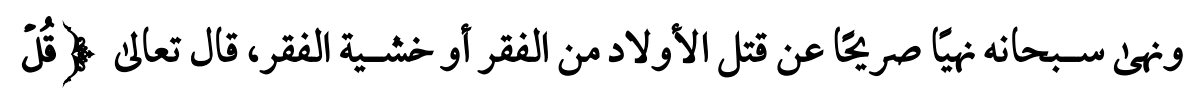

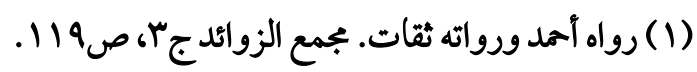

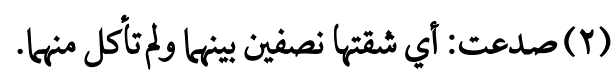

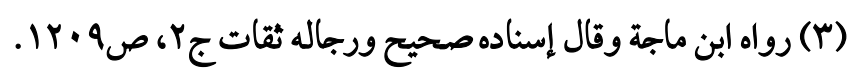

$$
\begin{aligned}
& \text { (ع) سورة الأنعام الآية (•ع) ). }
\end{aligned}
$$




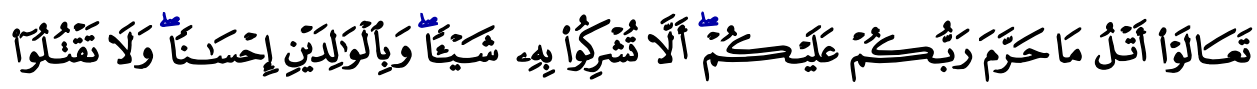

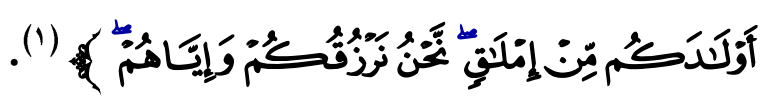

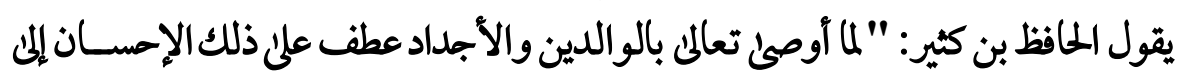

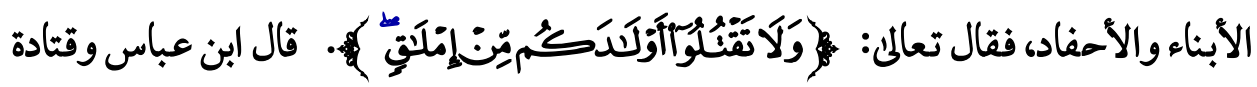
والسـدي وغيره: هو الفقر، أي ولا تقتلوهم من فقركم الحاصـل، وقال في سـورة الإسراءئز وَلَّا

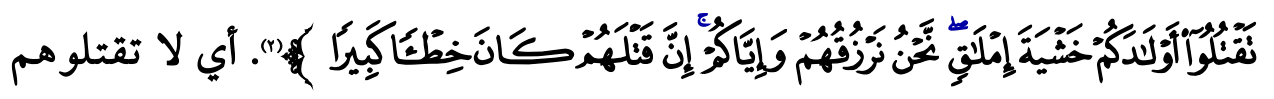
خوفا من الفقر في الآجل، ولهذا قال هناك نحن نرزقهم وإياكم فبدأ برزقهم للاهتحام بهم، أي

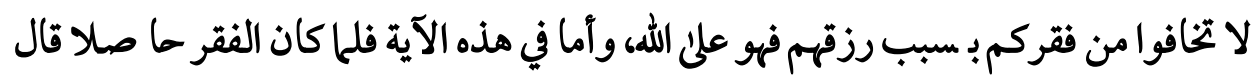

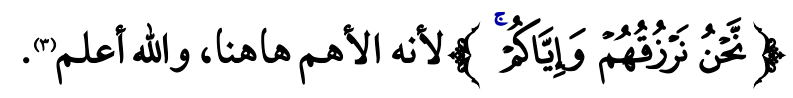
وتأمل النظم القرآني ودقة التعبير، فقد جاءت هذه الآية الكريمة التي في سورة الإسراء ولاء

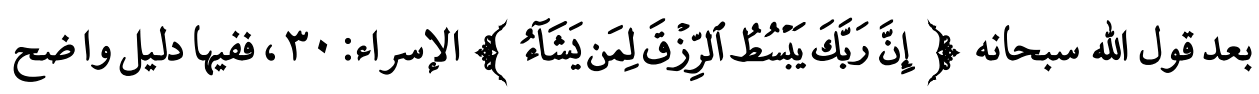

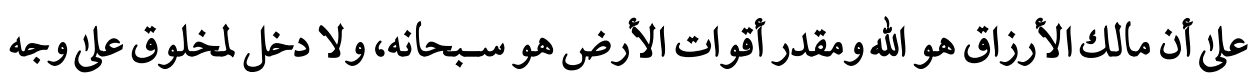
الأرض في رزق إنسان. وفي تقرير هذا النظم وجوه كما يقول الرازي:

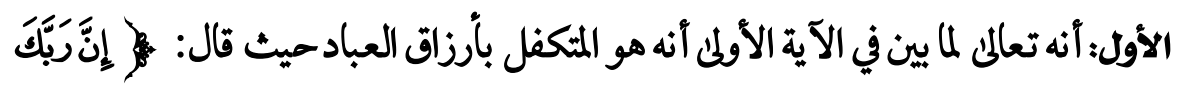

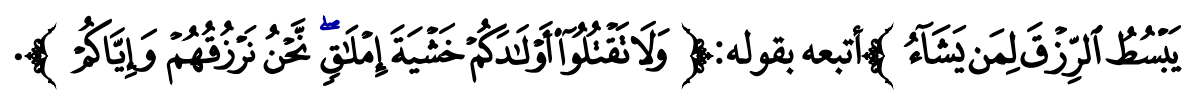

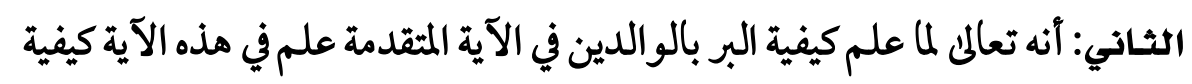
البر بالأولاد، ولمذا قال بعضهم: إن الذين يسمون بالأبرار إنما سموا بذلك؛ لأنهم برواليه الآباء

$$
\begin{aligned}
& \text { (1) سورة الأنعام الآية (101). } \\
& \text { (Y) سورة الإسراء الآية (Iال). }
\end{aligned}
$$

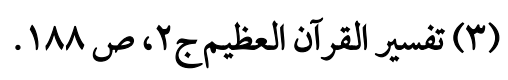


والأبناء وإنها وجب بر الآباء مكافأة علئ ماصــر منهم من أنواع البر بالأولاد وإنها وجب البر بالأولاد لأنهم في غاية الضعف ولا كافل بل لهم غير الوالدين.

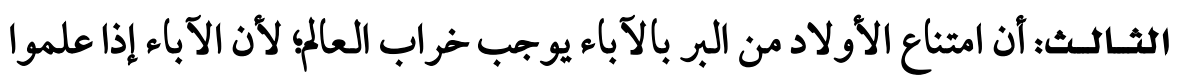
ذلك قلت رغبتهم في تربية الأولاد، فيلزم خراب العالممن الوجه الذي قررناه، فبت أبت أن عارة العالم إنما تحصل إذا حصلت المبرة بين الآباء والأولاد من الجانبين.

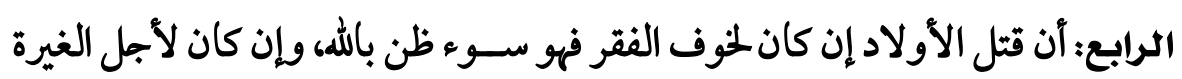

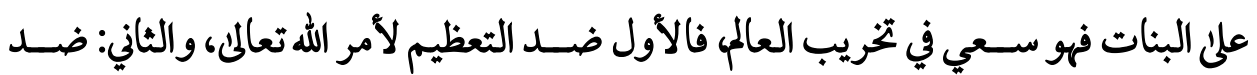

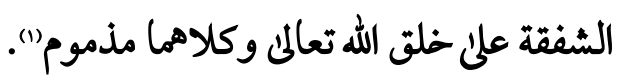
وإذا كان القرآن المجيد قد نهئ عن قتل الأولاد لأي سـبب وحرم ذلك فقد مرحت السنة المطهرة بأن هذا الفعل القبيح من أعظم الذنوب وأقبحها.

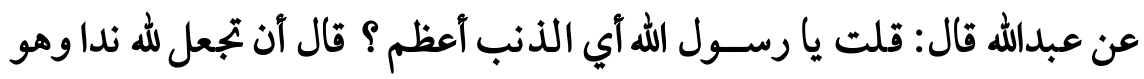

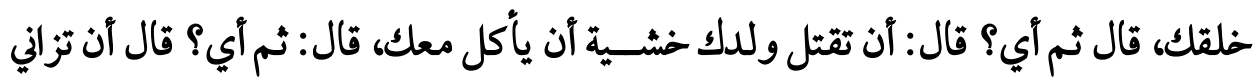

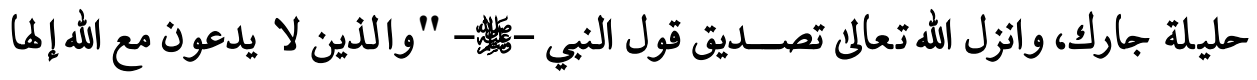
آخر" فا أحرئ المسلم أن يـ سير علئ هدي القرآن ليحظى بالثواب العظيم من الحق سبحانه وتعالم. وينال الرضا في الأولم والآخرة.

\section{منهج الإسلام في التزبية الوسطية؛}

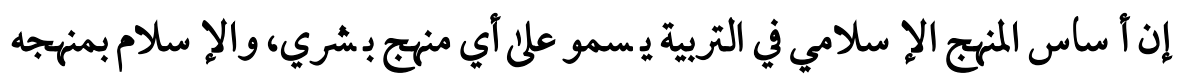
الفريد يغرس في نفوس الأبناء منذ الصسغر كل معاني الخير، وعلئ هذا " فهو يتكيف بحقاثق

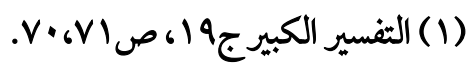

(Y) رواه البخاري في كتاب الأدب -باب قتل الولد خشية أن يأكل معه جrا، صص •ع. 
العلم الإلمي، لتصـير ملكة الخير طبيعته التي تصـدر عنها أفعال الخير بلا تكلف علئ يد مرب

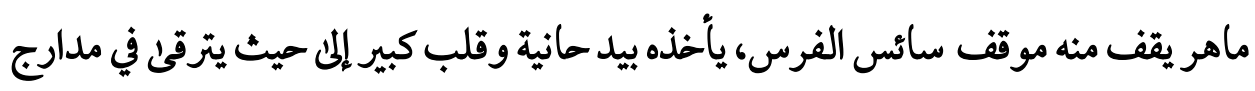
الكمال رويدًا عن طريق القدوة الحسنة. والعلم الصحيح، ولن يصل المربي-بمربيه- إلى هذا المستوى إلا على أساس القاعدة الصلبة- الإيان بالله وز وجل، بحيث تصبح العلوم الدنيوية

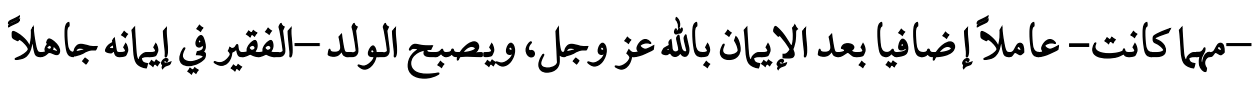
في منطق الإسلام مها كانت درجة تفوقه على زملائه

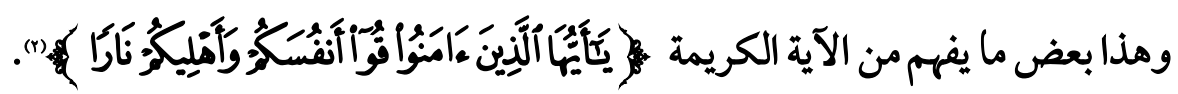
فلن يكون نجاح أو فوز وفلاح، ولن تكون نجاة مها حصـل من أعال الدنيا مالميكن ذلك

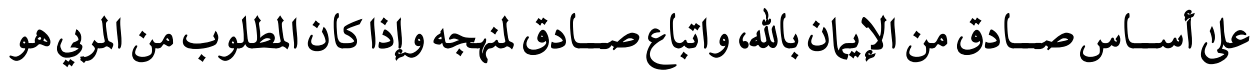
تعويد صغيره على معرفة أصول الدين وأحكامه حتىل يشب على الفضائل، فإن رسول الله -

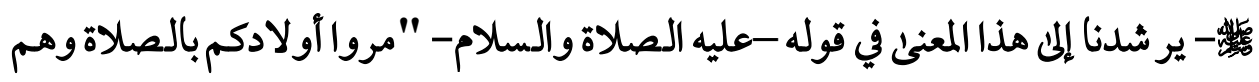
أبناء سبع سنين، واضربوهم عليها وهم أبناء عشر وفرقوا بينهم في المضاجع "(s).

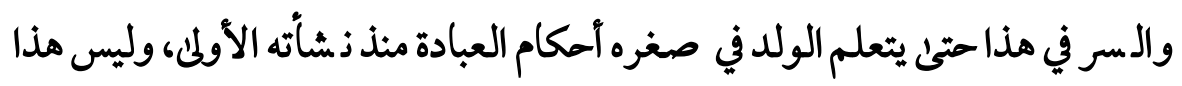

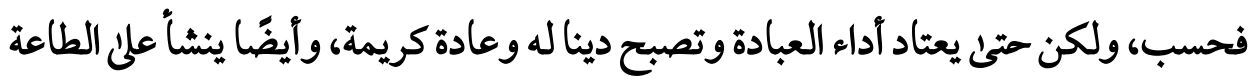
الحقة لله؛ ليجد الراحة النف سية والسكينة القلبية والطمأنينة، فضـالَّعن آن هذه العبادة التي يعتادها الصغير، هي تلبية للفطرة السليمة ونور للطريق الذي سلكه ويسير فيه، وتربية حقة على القوة في الدين والملق تمكنه من تحقيق مقاصــده السـامية وأهدافه النبيلة في الحياة، بعيدًا عن الشطط أو الزيغ؛ لأنها تحرره من الالتجاء إلى الرغبة الزائفة والشهوات القئ القاتلة، وتجعله

(1) (1) تربية الأولاد في ظل الإسلام ص111.

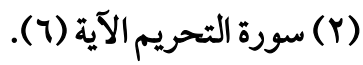
(Y) رواه أبو داود في كتاب الصلاة. 


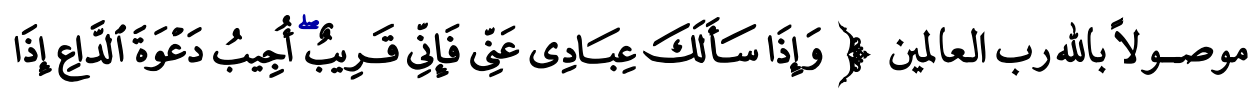

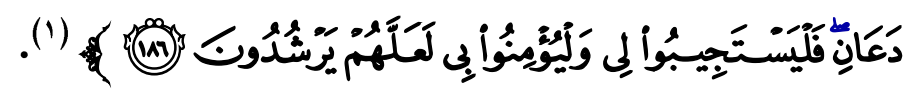

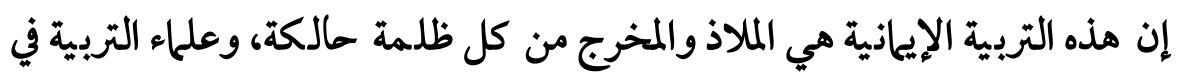
الغرب يعترفون بهذه الحقيقة. يقول طبيب النفس الأمريكي الدكتور هنري لنك: "إن هؤلاء

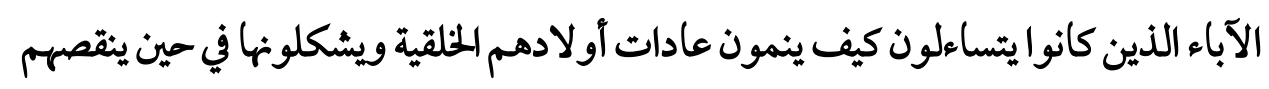
هم أنفسهـم تلك التأثيرات الدينية التي كانت قد شـكلت أخلاقهم من قبل كانوا في الحقيقة يجابهون مشـكلة لا حل لها، فلم يو جد بعد ذلك البديل الكامل الذي يجل محل تلك القوة

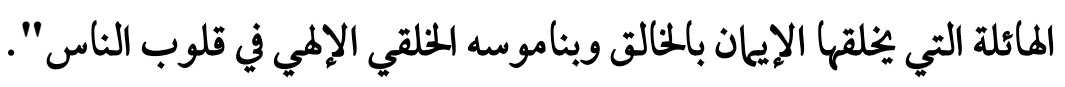

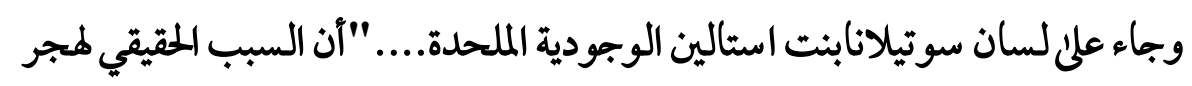

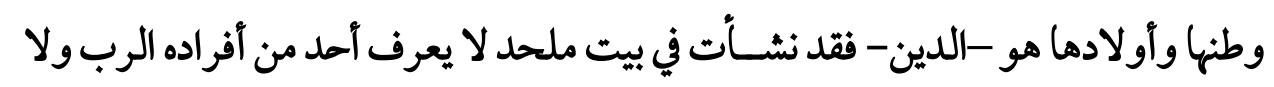

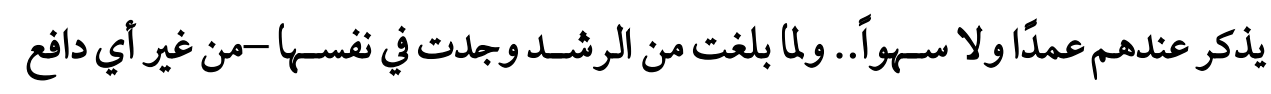

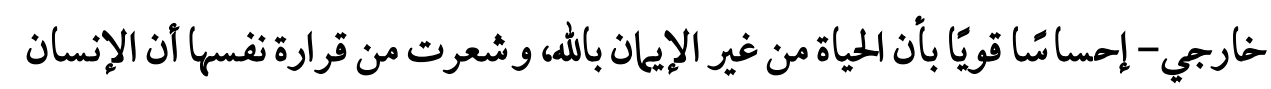
في حاجة إلى الإيان كحاجته إلى الملاء والمواء".

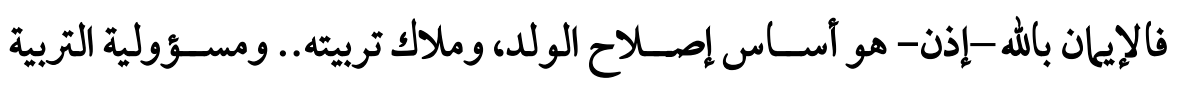

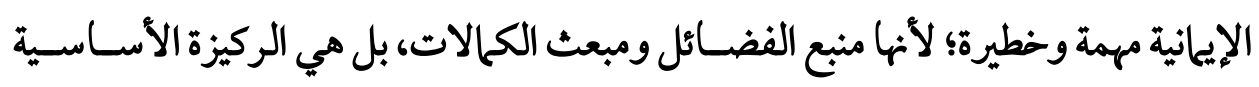

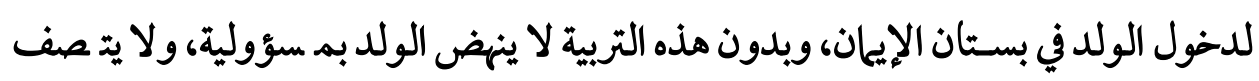

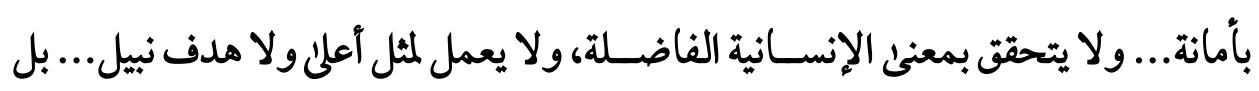

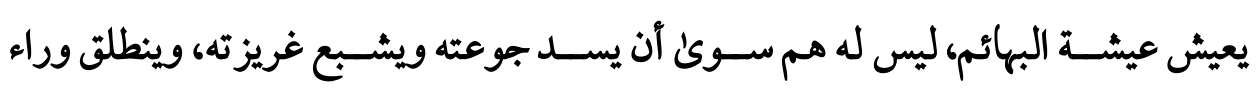

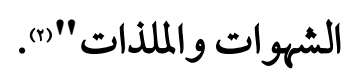

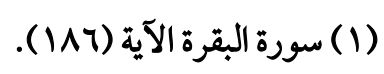

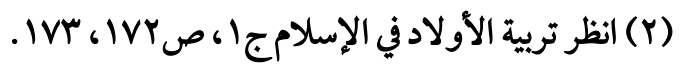


وما أحسن قول القائل:

قد ينفع الأدب الأولاد في صغر وليس ينفعهم من بعده أدب

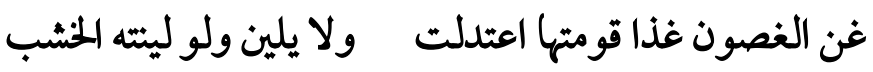

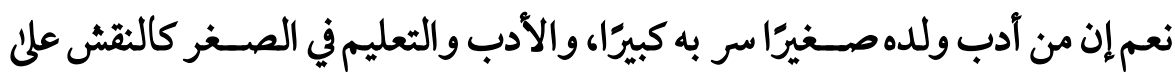

اللحجر، والأدب والتعليم في الكبر كالرقم علن الماء.

\section{البيئة وأثرها في التزبية:}

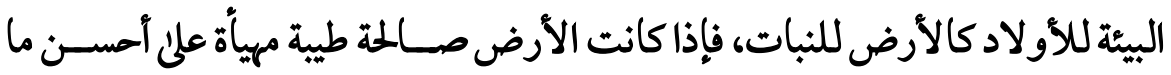

يكون لوضع البذور فيها؛ أنبتت يإذن ربها وآتت أكلها طيبا، كذلك البيئة بالنسبة للإنسان إذا مإنا

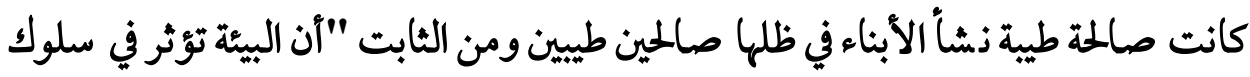

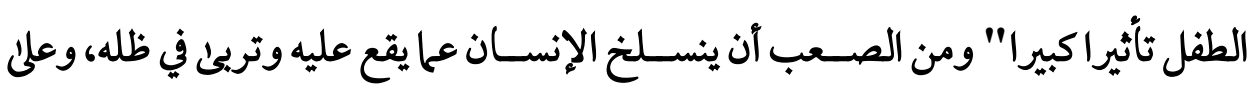
ضوء ذلك يجب أن ينشاً الطفل في جو ديني يهفظ القرآن وبعضًا من الأحاديث النبوية المتعلقة

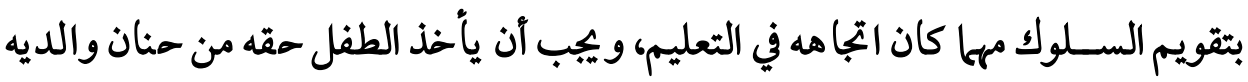
وعطفها، ولا سيا الأم في مرحلة الطفولة المبكرة" (1).

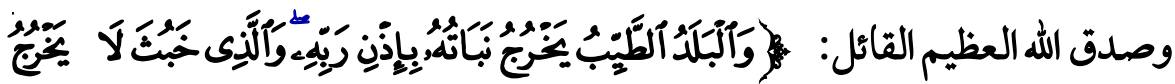

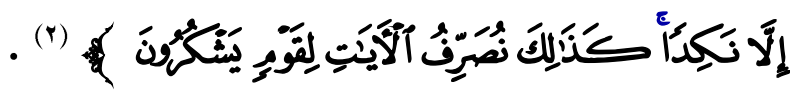
"قال علي بن أبي طلحة عن ابن عباس في الآية: هذا مثل ضركر به الله للمؤمن والكافر، وفي البخاري عن إي موسئ قال: قال رسول اللهصلئ اللهعليه وسلم " امثل ما بعثني الله به من

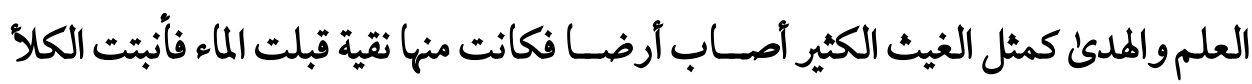
والعشب الكثير وكانت منها أجادب أمسكت الماء فنفع اللهبها الناس فشربوا وسقوا وزرعوا

(1) منجج القرآن في تهذيب الغريذة ص ابا. (Y) سورة الأعراف الآية (ON). 
وأصـاب منها طائفة أخرى إنما هي قيعان لا تمسـك ماء ولا تنبت كلاً فذلك مثل من فقه في دين الله ونفعه ما بعثني الله به فعلم وعمل ومثل من لم يرفع بذلك رأسـا ولميقبل هدئ الله

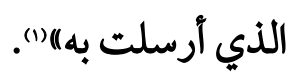

\section{من التربية العلية الوسطية في القرآن الكريم:}

القرآن المجيد كله تربية وآداب يجب الالتزام بها، وتنشسئة الأولاد عليها، وهذا نموذج قرآئي أسوقه لتعلم أصول التريية الإسلامية، وقدجاء مذا النموذج في صورة وصية غالية صادقة من ولد صالحصادق في نصحه لابنه، إنه لقمان الذي سميت السورة الكريمة باسمه، ليتعبد بتلاوتها، أعطاه

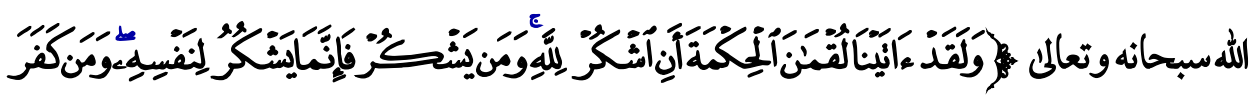

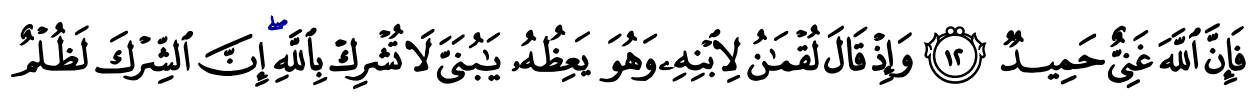

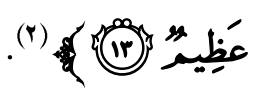
هذه أول وصية من الوصايا العظيمة ينادي الوالد الناصح على ابنه - يا بني - بالتصغير

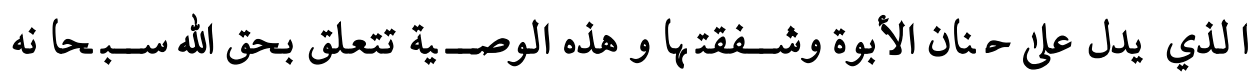

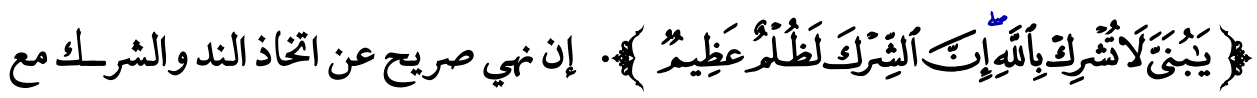
الله؛ لأن الشركـك هو آقصر-طريق إلى التمزق والانحلال في كل شيءء بينما التوحيد والإييان

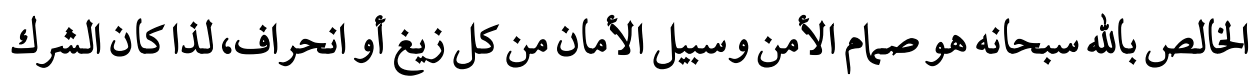

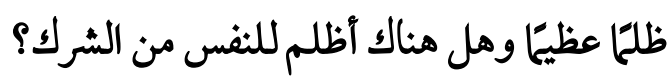

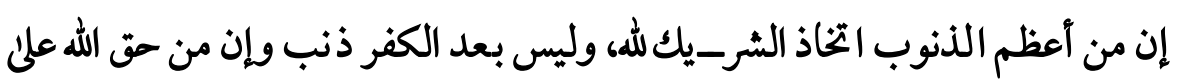

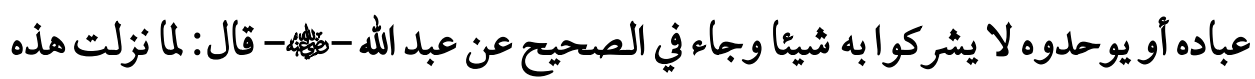

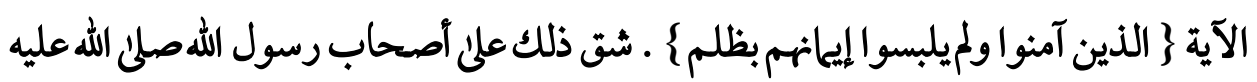

(1) تفسير ابن كثيرجYr ص ص YrYr، و والحديث رواه البخاري في كتاب العلم. (Y) سورة لقحان الآية (Y Ir- Ir). 


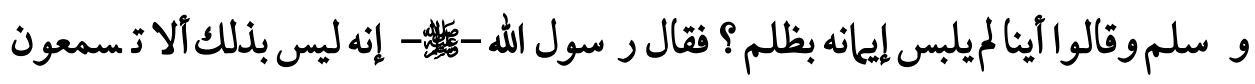

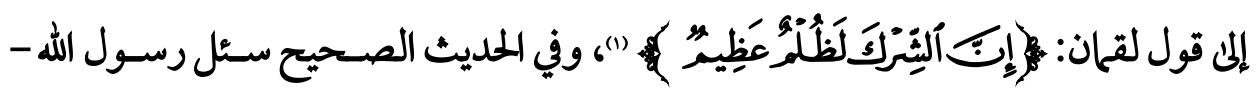

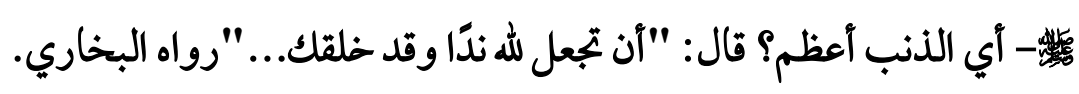

\section{المراقبة الداتية:}

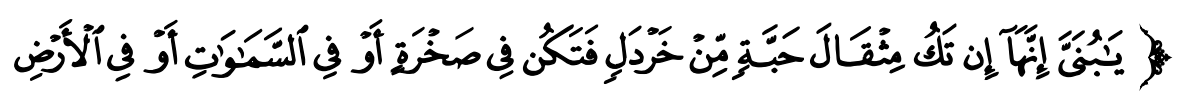

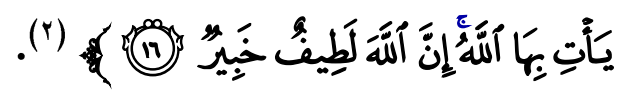

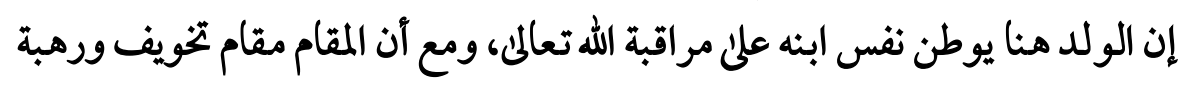

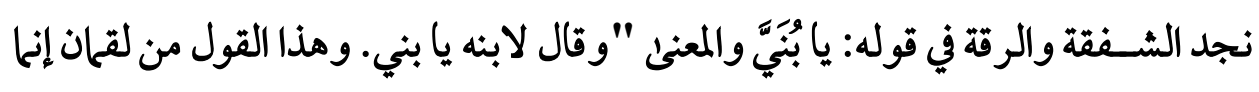

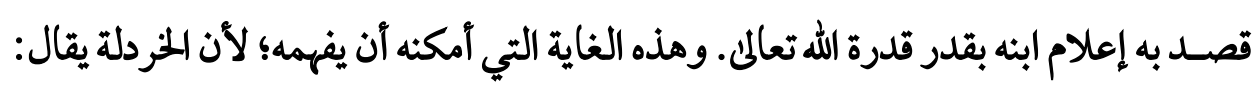

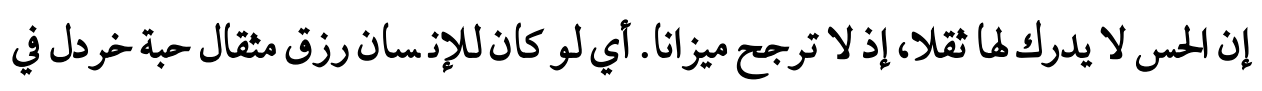

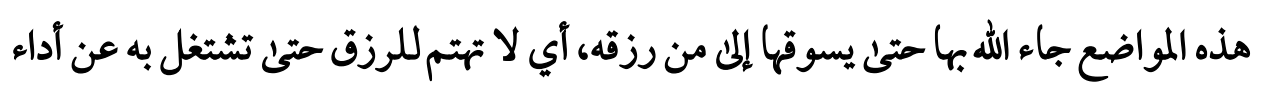

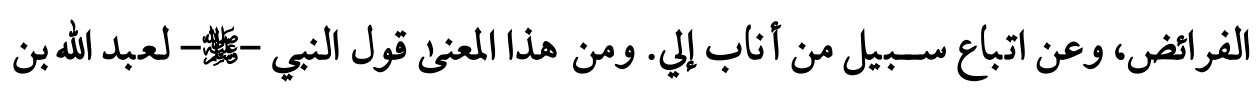
مسسعود: (لا تكثر همك ما يقدر يكون وما ترزق يأتيك). وقد نطقت هذه الآية بأن الله تعلى منيل

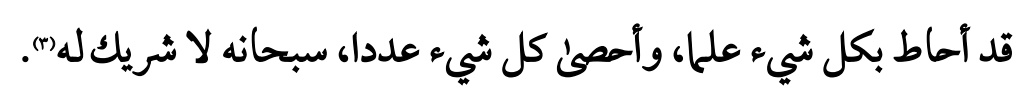

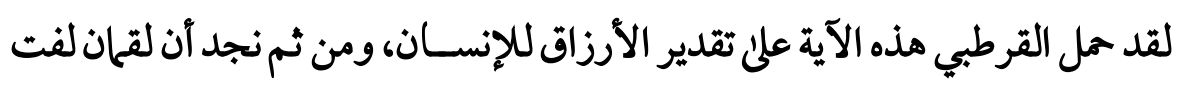

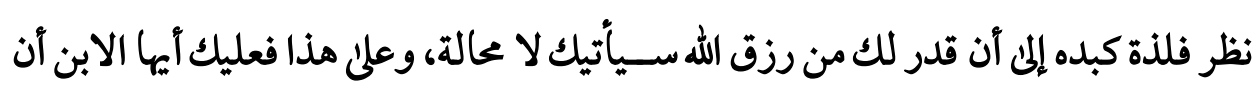
تكون ملازمًا للطاعة.

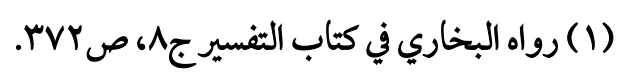

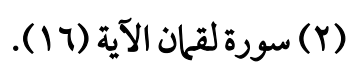

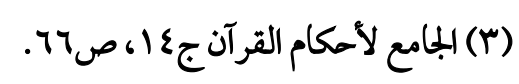


وأرئ... أن حمل الآية علنيل للخوف والمراقبة أولى؛ لأن الأرزاق وتقديرها أمر معلوم، ولكن الآية

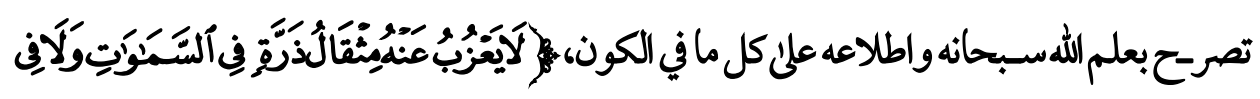

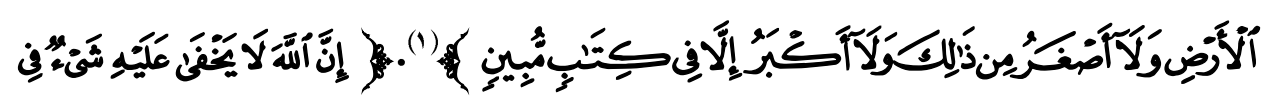

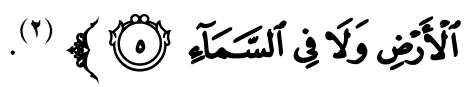
فكأنه يقول له: إياك أن تعمل في السر_-عملاً يبعدك عن الله؛ لأنك إن لم تكن تراه فإنه يراك. وأن الفعلة من الإســاءة والإحسـان إن تك وزن حبة من خردل فتكن في أخفىل مكان وأحرزه كجوف الصخرة أو في أعلى مكان كالسموات، أو في أسفله كباطن الأرض يخضرها

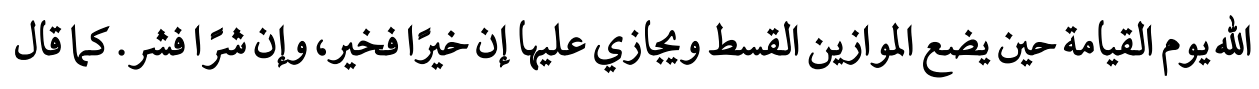

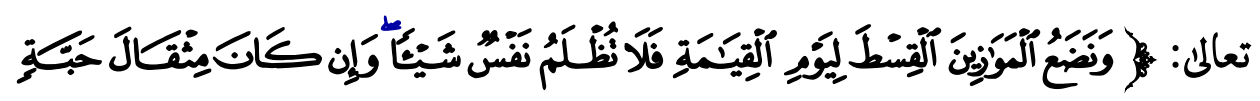

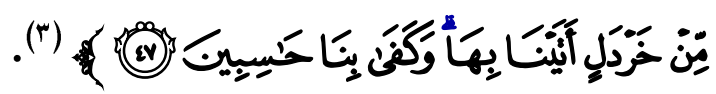

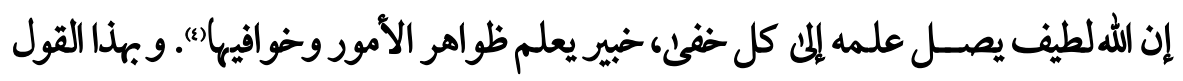
الكريميو ضح الآباء لأولادهم معنى للخوف ممن لا ينقى عليه شيء فعلمه سبحانه لايحد، وإنما هو علم مطلق شامل ومحيط بكل أسرار الوجودوخفاياه. ومن ثمإذا تمكن الابن من فعل شر وهو بعيد عن رؤية أبيه وعن علمه فإنه لن يفلت أوينجو من

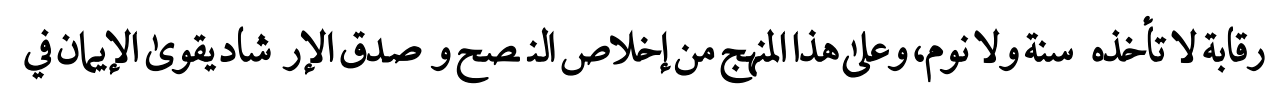
قلوب الأولادوترسخ الحناق الفاضلة في نفوسهم.

$$
\begin{aligned}
& \text { (1) سورة سبأ الآية r. } \\
& \text { (Y) سورة آل عمران الآية ه. } \\
& \text { (ب) سورة الأنبياء الآية Vع. }
\end{aligned}
$$

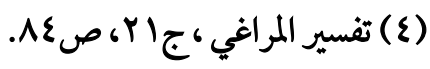




$$
\text { يا بني آقم الصلاة: }
$$

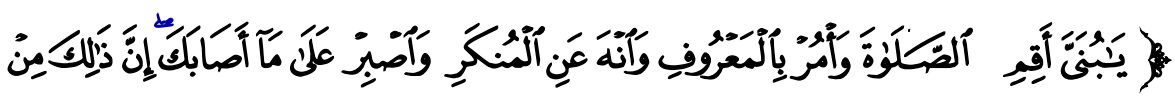

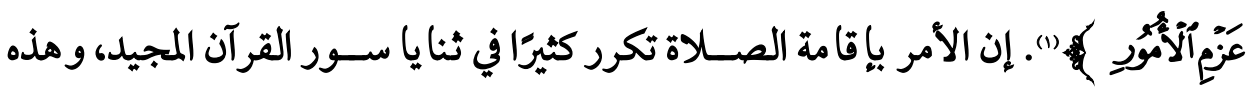
الفريضة تتكرر في اليوم خمس مرات، وهي معراج دائم إلى الله سبحانه.

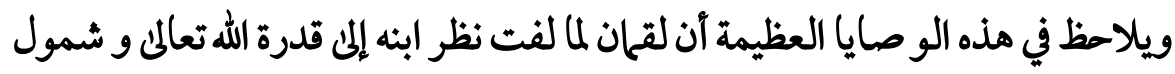
علمه وإحاطته بالوجود كله، امره بعد ذلك بـا ينفعه ويكون سـببا في رفع درجاته، وهو في

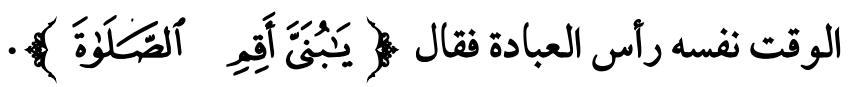

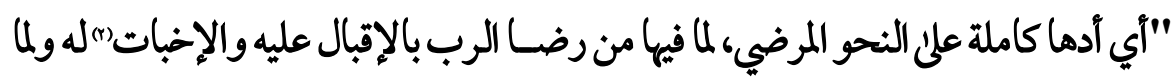

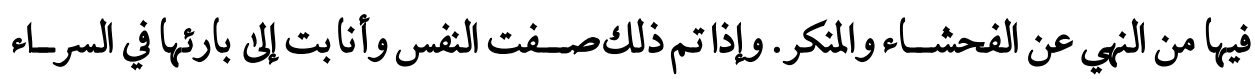

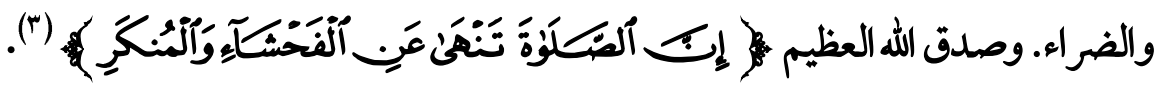
ولا يففى ما للصـلاة من أثر على الفردوالمجاعة، إنها تمنح الإنسـان يقينًا وتفيض عليه

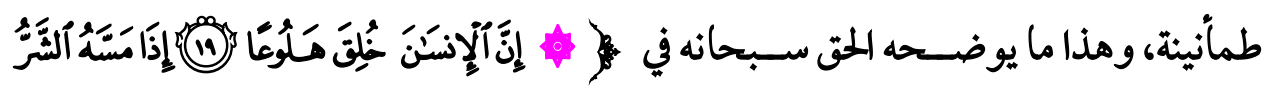

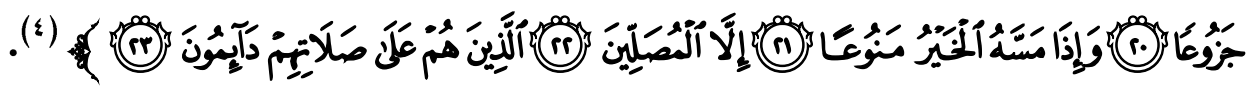

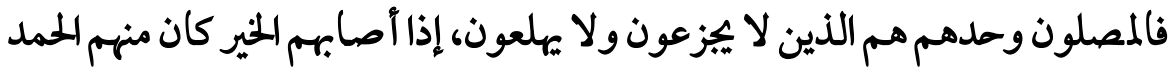
والشـكر لواهبه ومانحه، وإذا أصـابهم الشر-والمكروه كان منهم الصسير واللياذ إلى خالقهم

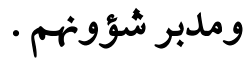

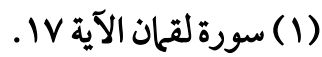
(Y) خبت أخبت الرجل إخباتًا بمعنى خضع لله وخشع قلبه قال تعالث: ويشر المخبتين -المصباح المنير،

$$
\begin{aligned}
& \text { ص. •r. والإخبات الرجوع. } \\
& \text { (Y) سورة العنكبوت الآية هـ. } \\
& \text { (§) سورة المعارج الآيات 19-19 }
\end{aligned}
$$


والآيات الكريات تكشـف عن حقيقة الإنســان، يفرح عند النعمة والعطاء، وتظلم

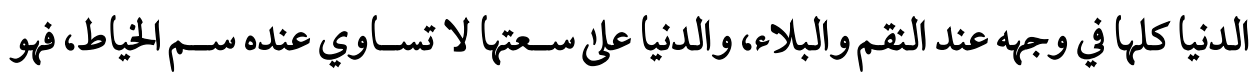
دائم الضجر كثير الشكوئ، يسيطر عليه اليأس من كل جانب، لكن الذين هم علن صلاتهم دائمون منحهم الله سبحانه - مضانة- من هذه الأشياء، يقول ابن كثير:

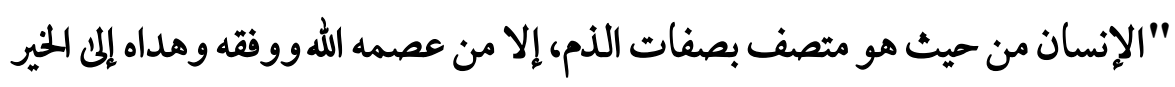

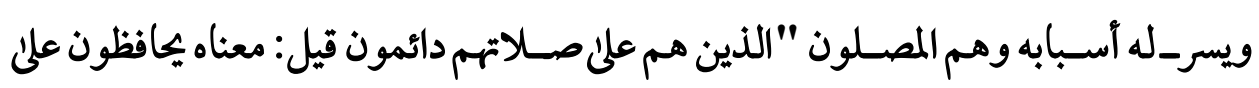
أوقاتها وواجباتها، قاله ابن مسعودوغيره، وقيل: المراد بالدوام هنا السكون والمشتوع كقوله

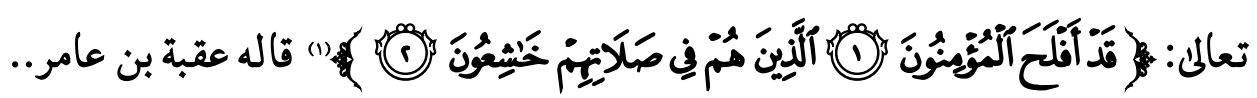

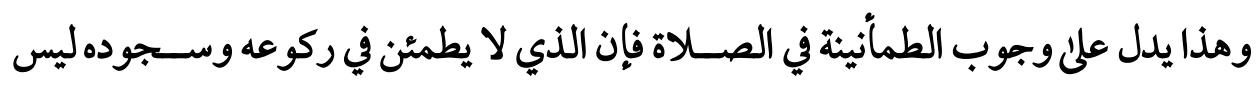

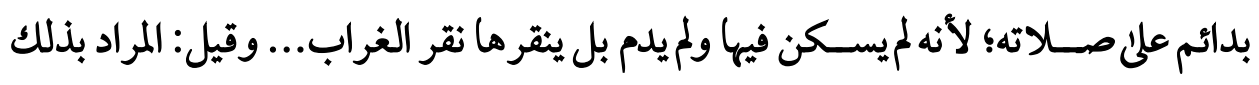
الذين إذا عملوا عملا داوموا عليه وأثبتوهة).

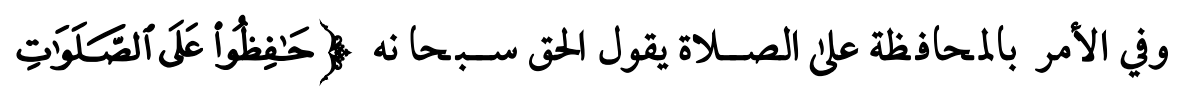

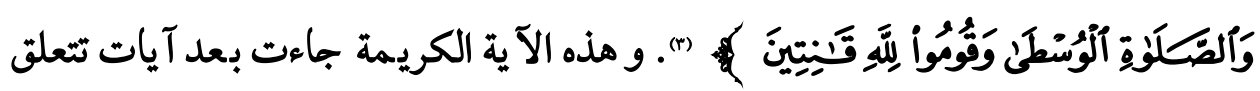
بأحكام الأولادو الأزواج والطلاق ومشاكله والأسرة. وريجا دل ذلك على الصلة الوئيقة بين الصلاة ومس ستقبل الأسرة؛ لأنها -أي ال صلاة-

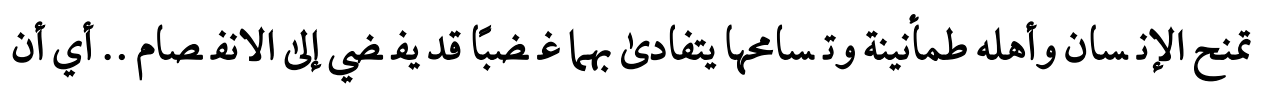

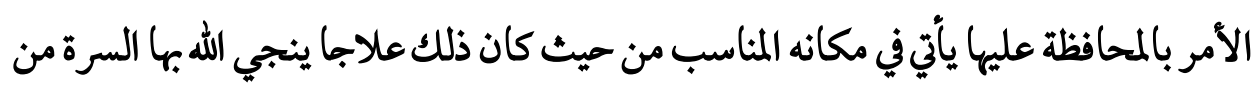

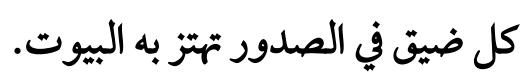

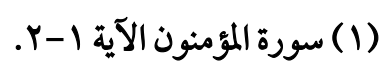

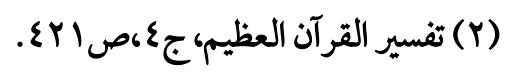
(r) سورة البقرة الآية (Yr. 
وبعد الأمر بإقامة الصلاة جاء الأمر بالأمر بالمعروف والنهي عن المنكر والصبر علئ ما يصيب " وأمر بالمعروف وانه عن المنكر واصبر علن ما أصابك إن ذلك من عزم الأمور".

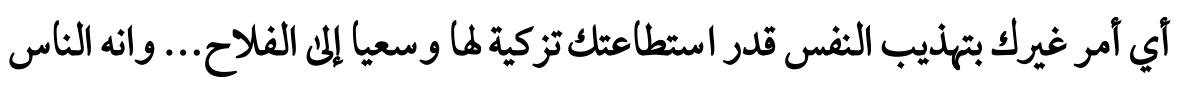
عن المنكر وعن معاصي الله ومحارمه التي تويق من اكتسبها، وتلقي به عذاب السعير في جهنم وبئس المصير.

ولا تظن آن طريق الأمر بالمعروف والنهي عن المنكر مفروش بالورود والر ياحين ولكنه طريق شاق قد يصيبك فيها مكروه، وإذا حدث هذا فاصبر علئ ما أصابك.

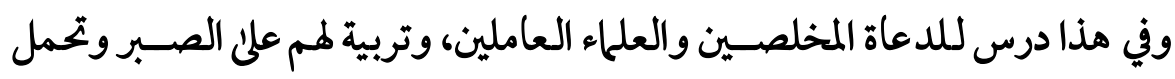
المشــاق مها كلفهم ذلك فإن هذا "من عزم الأمور". "أي أن هذه الطاعات المذكورة التي

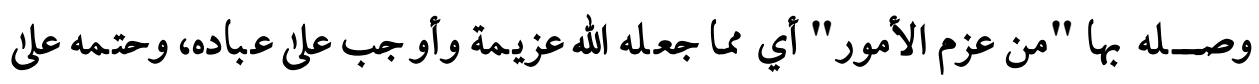

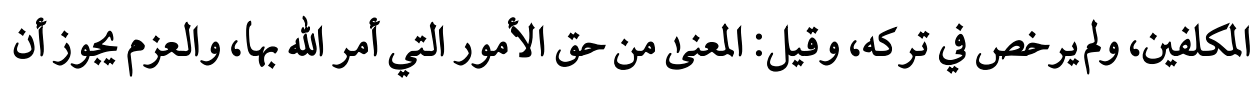

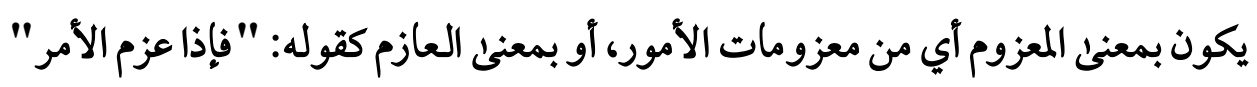

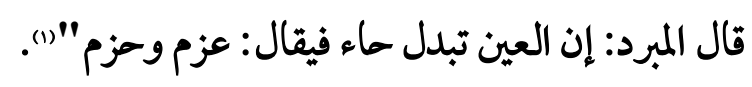

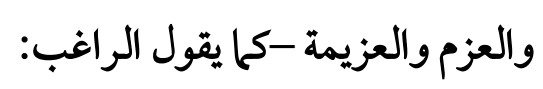

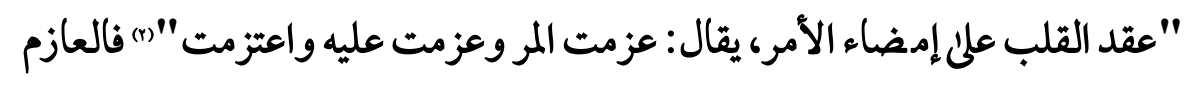
علن شيء من الحير الواجب النفاذ، والالتزام بها من حقيقة الإيانان.

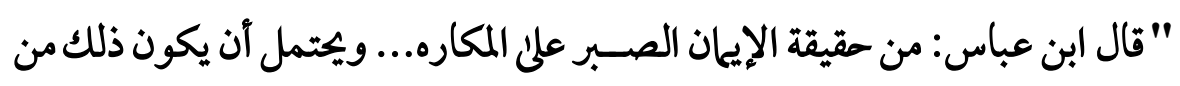
مكارم الخلاق، وعزائم أهل الخير والحزم السالكين طريق النجاة" "(r).

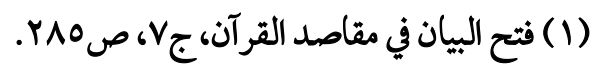

$$
\begin{aligned}
& \text { (Y) المفردات في غريب القرآن، صع (1) }
\end{aligned}
$$

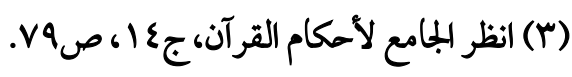




\section{نهي وتحلئير:}

لقدجاءت الو صايا السابقة آمره بالفضائل وهي تتعلق بجنب الله سبحانه وتعلايلى

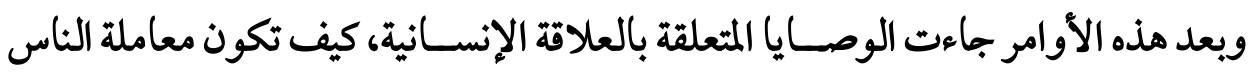
بالتواضـع الجمم، والطلق الرفيع، وإذا كان الابن في مرحلة شـبا به وعنفوا نه ينمو لديه الإهساس بالذات، ويكثر عنده الاستمساك بالرأي -بل والإعزاز به- فإن ذلك ريجا يقوده إلى التكبر علن أقرانه، والزهو والخيلاء، وهذا المسلك من شأنه أن يقطع و شيجة العلاقة بالله وبالناس.

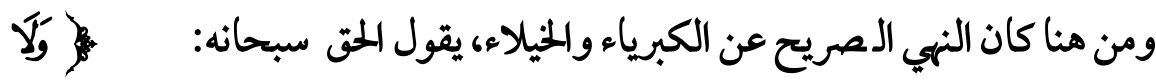

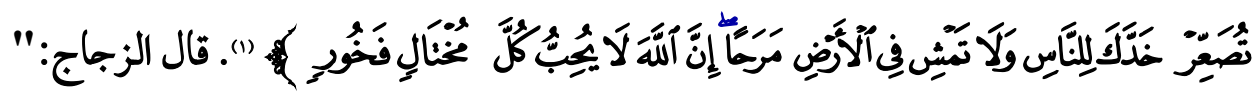
ويقرا تصاعر، وييوز في العربية:ولا تصعر -بسكون الصادوكسر العين-، ولا أعلم آحدا

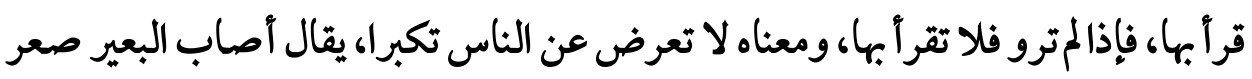

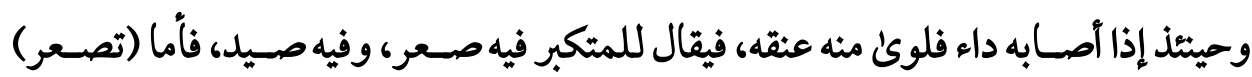
فعلئ وجه المبالغة، ويصاعر جاء على معنى يفاعل، كأنك تعارضهم بوجهك، ومعنى (تصعر) تلزم خدك الصعر؛ لأنه لا داء بالإنسان أدوا من الكبر" (i) . إن هناك صنفًا من الناس يلوي عنقه، ويلجاً إلى ذلك في مظهر خادع كاذب قد تسول له نفسه الأمارة أن هذا الصنيع من مقومات الشخصية، ودليل على الاعتزاز بالنفس والثقة، وهو يفعله تكبرًا وزهوا، وذ سئ آن التوا ضع وخفض الجناح من صهام أمن وأمان، وطريق

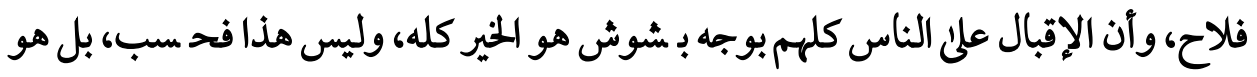




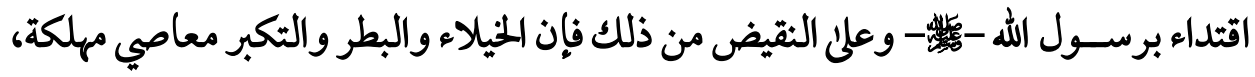
تبعد الإنسان عن الله وتعرضه لسخطه وغضبه. ففي الصحيح يقول رسول الله -

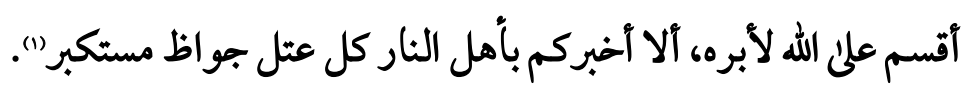

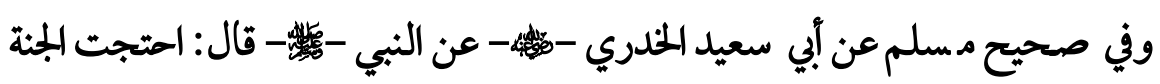
والنار، فقالت النار في الجبارون والمتكبرون، وقالت الجنة: في ضعفاء المسلمين ومساكينهم. فقضى_ الله بينها أنك الجنة رحتي آرحم بك من أثـاء، وأنك النار عذابي أعذب بك من أشـاء،

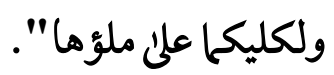

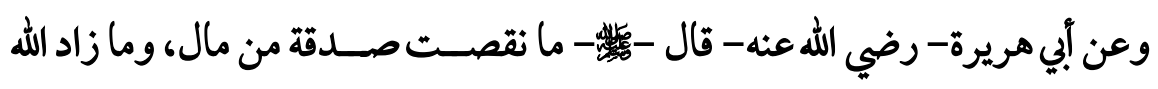
عبدًا إلا عزَّا، وما تواضع أحدًا إلا رفعه اللهان. ويكفي المصعر خده تكبرًا أنه من أهل النار، وح سب المتوا ضع آنه من أهل الجنة كما

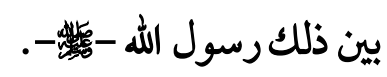
ولا تمش في الأرض مر حَا: "أي لا تمش خيلاً وتكبرًا، والمراد النهي عن التكبر والتجبر، والمختال يمرح في مشـيته. "إن الله لا يحب كل مختا فحور " تعليل للنهي المذكور؛ لالان الاختيال هو المرح.. والفخور هو الذي يفتخر على الناس بنا له من الملال أو الشرـف أو القوة، أو بعدد مناقبه تطاولا، ويظن أن إســباغ النعم الدنيوية عليه من محبة الله له، وذلك من جهله، فإن الله تعالى أسبغ نعمه على الكافر الجاحد فينبغي للعارف أن لا يتكبر" (r).

(1) رواه البخاري في كتاب الأدب -باب الكبر، ج؟1، ص 1 + ا والعتل الغليظ الجافي- والجواظ الجموح

$$
\text { المنوع وقيل الضخم المختال في مشيته. }
$$

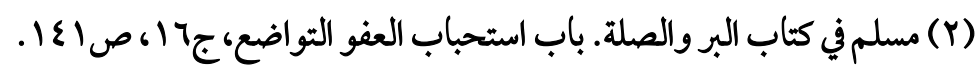

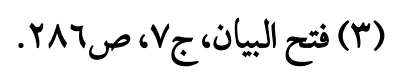




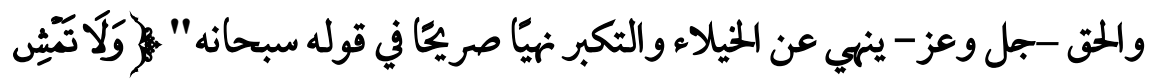

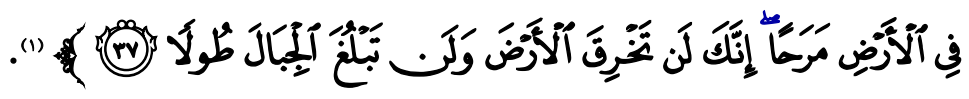

\section{يقول الإمام القرطبي؛}

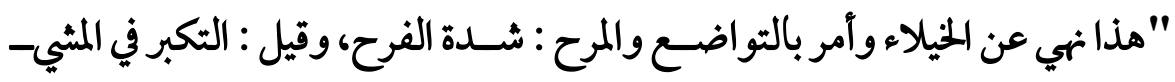

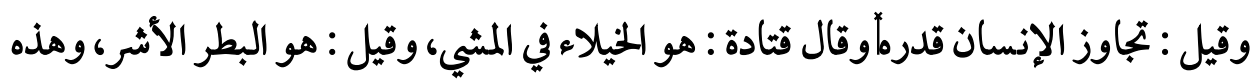

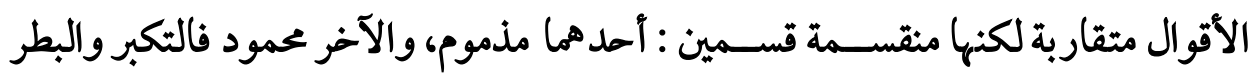
والخيلاء وتجاوز الإنسان قدره مذموم، والفرح والنشاط محمود....

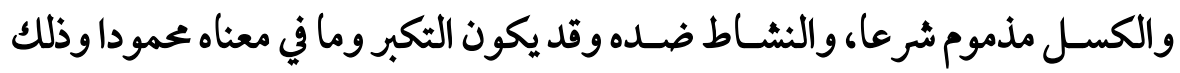
على أعداء الله والظلمة... وأنشدوا:

$$
\text { ولا ولا تش فنت فوق الأرض إلا تواضعا ... فكم تحتها قوم همو منك أرفع }
$$

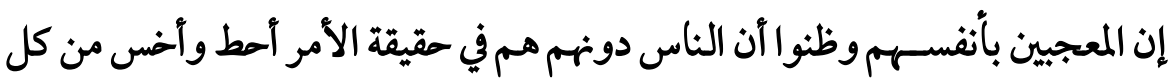
ما سواهم، ولو لميكن لهم من مهانة وحقارة إلا أن الله لا يجهم لكفئ هذا شناعة لهم. وازدراء

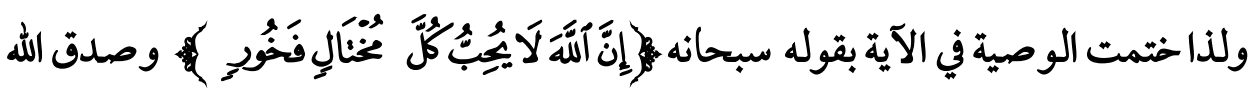

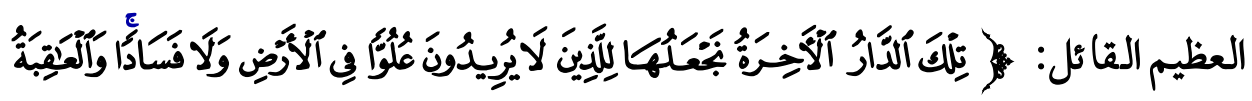

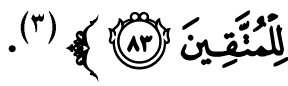

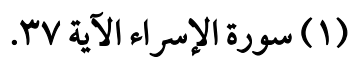

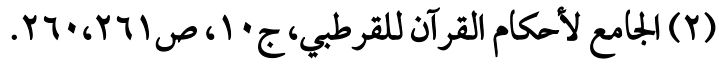
(Y) سورة القصص الآية ب؟1. 
واقصد في مشيك: بأسلوب الوالد الناصح يرسم لقحان لابنه خطى المنهج السوئ، فلما نهاه عن الخلق الذميم، أعقب ذلك الأمر بالملق الحميد فقال كما حكئ القرآن المجيد

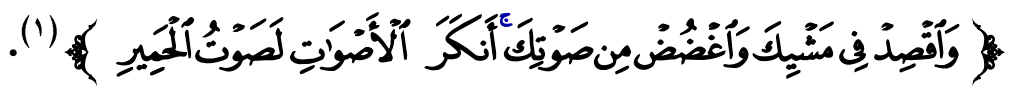

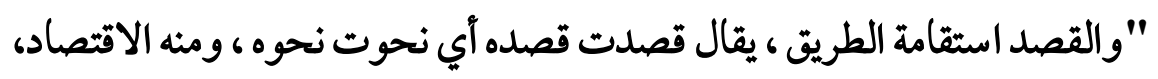

والاقتصـاد علإ ضربين : أحدهما محمود على الإطلاق وذلك فيال له طر فان. إفراط وتفريط

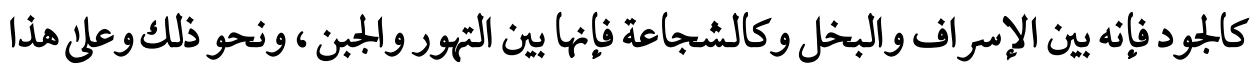
قوله " واقصد في مشيك " والثاني يكنى به علا يتردد بين المحمود والمذموم وهو فيا يقع بين محمود ومذموم كالواقع بين العدل والجور، والقريب والبعيد وعلئ ذلك قوله " فمنهم ظالم لنفسه ومنهم مقتصد (r)" وقوله : "و سفرا قاصدا " أي سفرا متو سطا غير متناهي البعد وليد

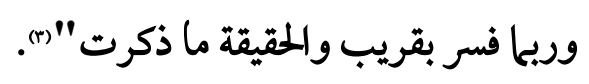

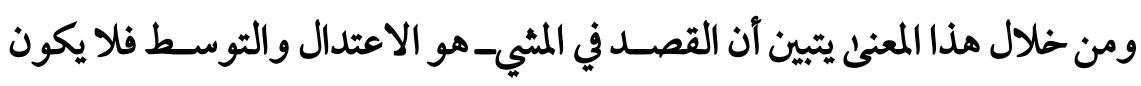
المشي في سرعة هوجاء، ولا في بطء ميت كأن الماثي مريض وخير الأمور أو سطلا، والقصد يتين

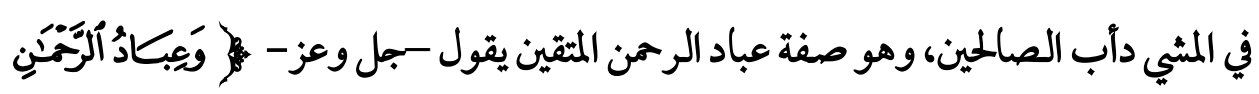

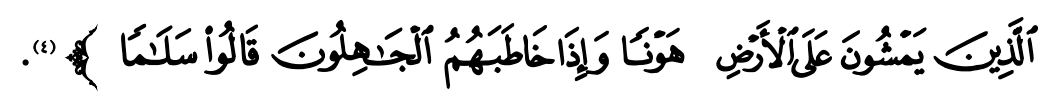

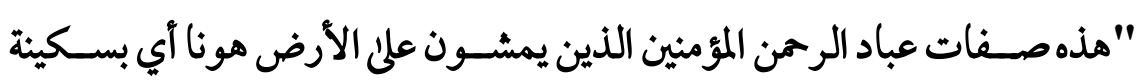

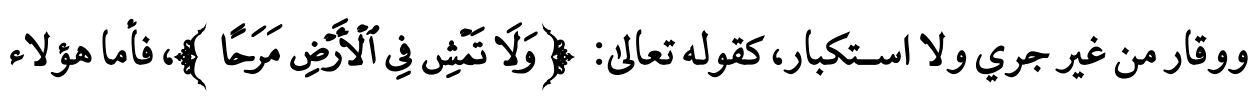

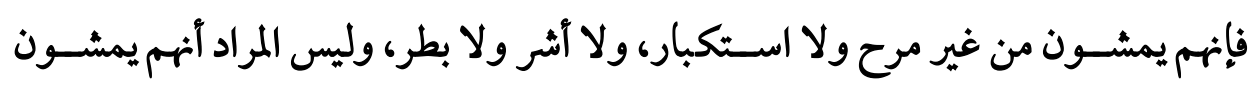

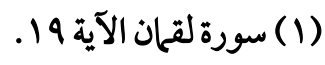

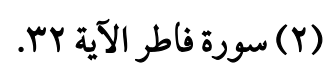

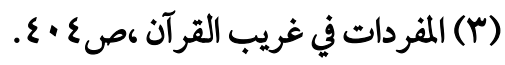
(ع) سورة الفرقان الآية سآ. 
كالمرضى تصنعا ورياء، فقد كان سيد ولد آدم -

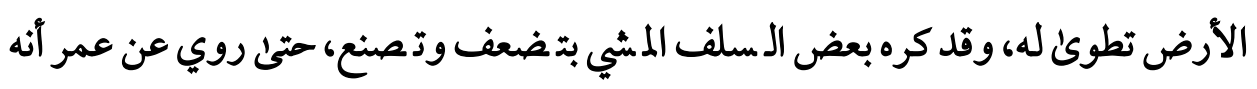

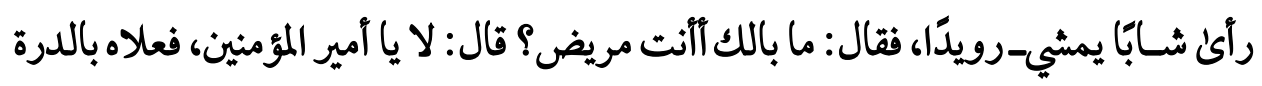
وأمره أن يمشي بقوة...والمراد بالمون هنا السكينة والوقار "(1).

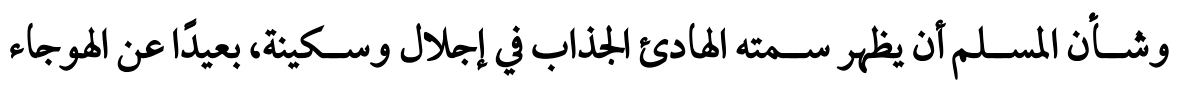
والمظهر السيء المشين. "و قال الزهري: سرعة المشي_ تذهب بهاء الوجه، و قال ابن عطية: ير يد الإسراع

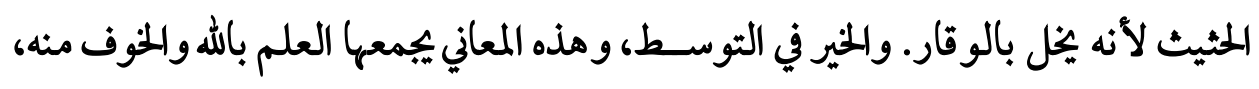
والمعرفة بأحكامه والمنشية من عذابه وعقابه، جعلنا الله منهم بفضله ومنه، وانشد ابن العربي: تواضعت في العلياء والأصل كابر وحزت قصاب السبق بالمون في الأمر

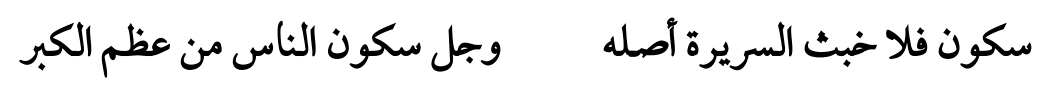

وبعد أن أمر لقمان ولده بالقصد في المشبي أعقب ذلك بو صية جلئ جليلة وهي تتعلق أيضًا

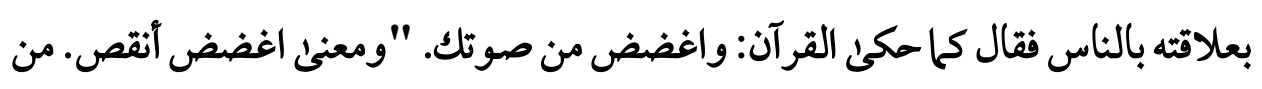
غضضت بصري، وفلان يغض بصره من فلان اي ينقصه" ().

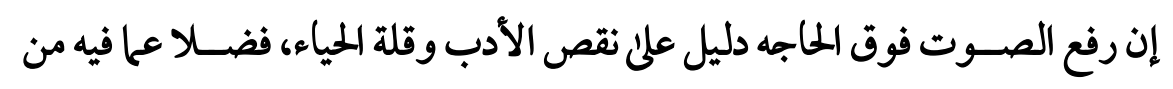

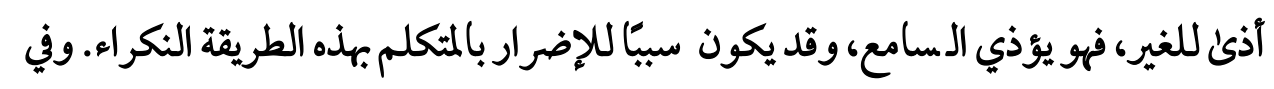

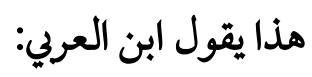
"لا تتكلف رفع الصسوت وخذ منه ما تحتاج إليه. فإن الجهد بأكبر من الحاجه تكلف العري

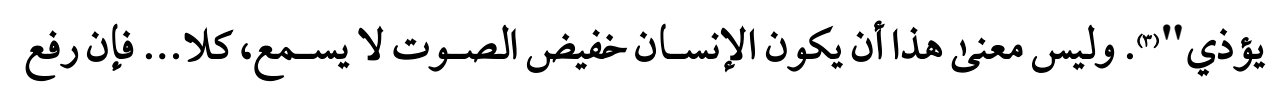

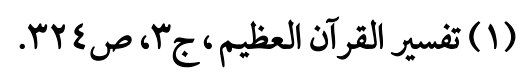

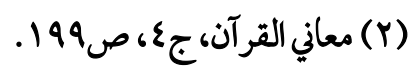

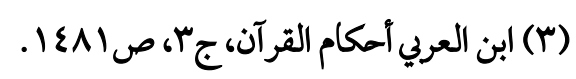


الصــوت قد يكون مطلوبًا لماجة تدعو إليه، وذلك كرفعة الأذان، وكذلك التحدث أمام جمع

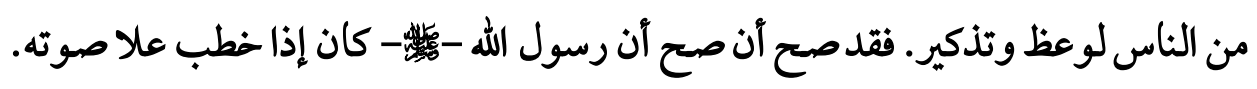

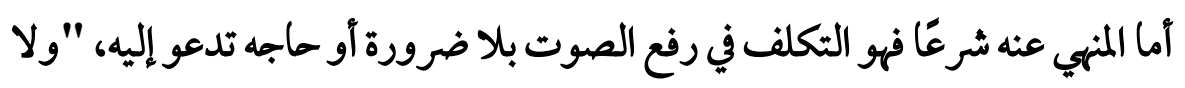

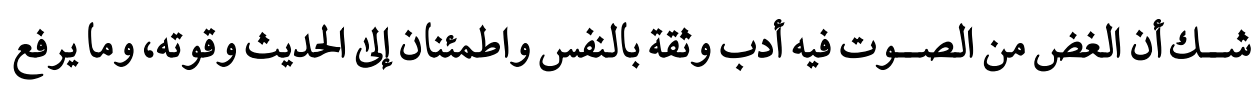
صوته أو يغلظ في الخطاب إلاسيء الأدب، أو شاك في قيمة قوله، أو قيمة شخصيته، يحاول

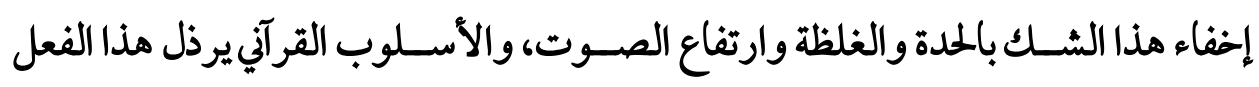

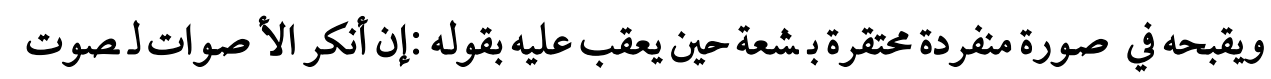
الحمير" فيرتسم مشهد مضحك يدعو غلن المزء والسخرية مع النفور والبشاعة".

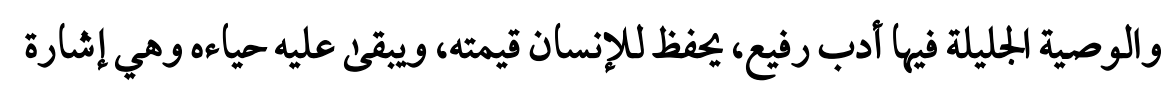
إلى التوسط والاعتدال، ليس في هيئة الإنسان وسمعته ولكن في قوله أيضًا.

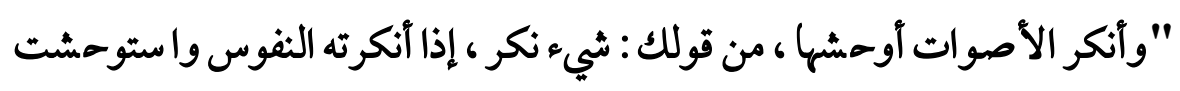
منه ونفرت ـ والحمار مثل في الذم البليغ والشتيمة ، وكذلك نهاقه ـ ومن ا ستفحا شهم لذكره

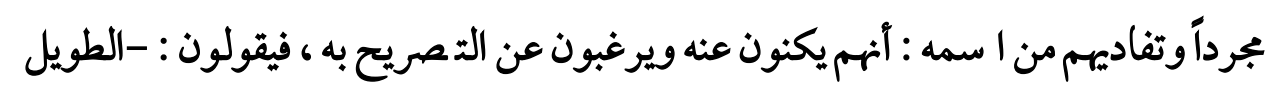

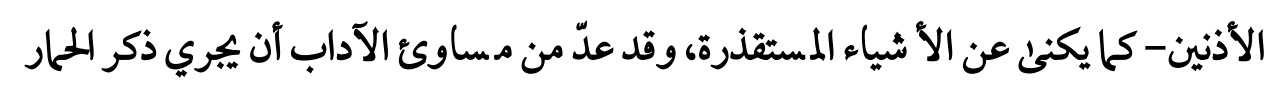

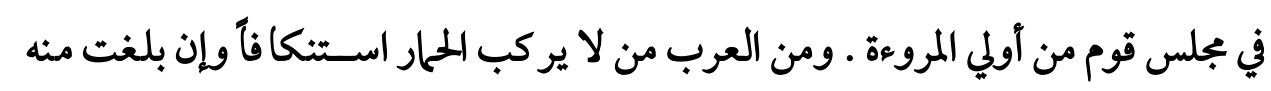

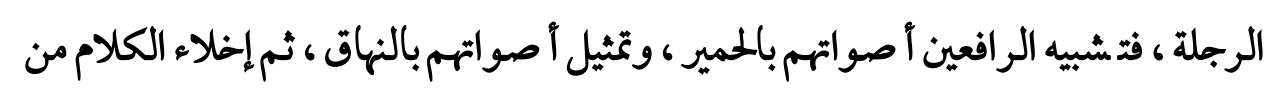

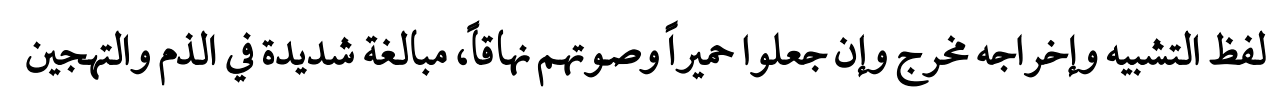
وإفراط في التبيط عن رفع الصسوت والترغيب عنه، وتنبيه على أنه من كراهة اللهبمكان" (1).

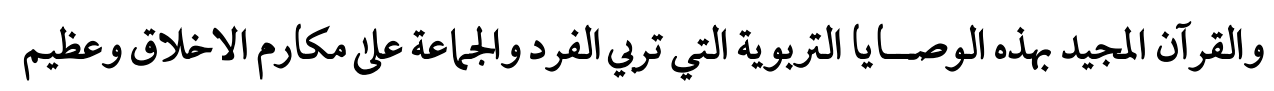

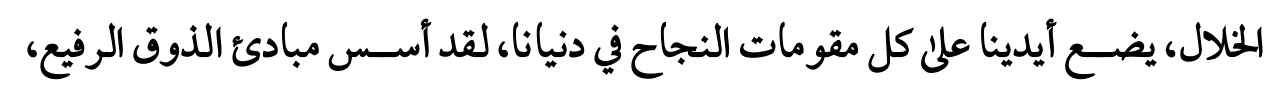


وهذه المبادئ "يضعها القرآن بين أيدينا على نحو يظهر به عوار المدنية الحديثة فيا وافتنا به من

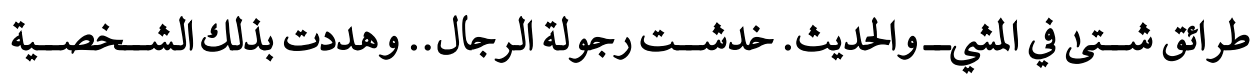
الإ سلامية. التي يخشئ عليها من دوامة التقليد أن تفقد عناصر بقائها، وهذا ما تحاول المدنية

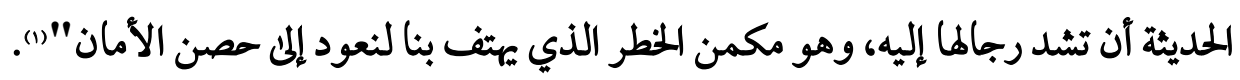

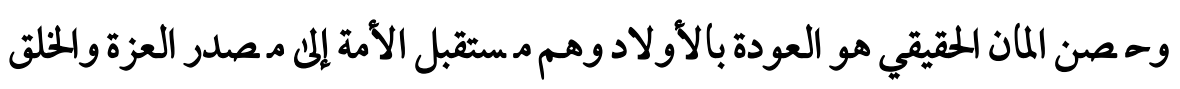
القويم وهو تنشتتهم على آداب الإ سلام السامية، وأخلاقه الفا ضلة والاعت صام بحبل الله الذي لا تفصم عراه" ومن يعتصم بالله فقد هدئ إلى صراطِ مستقيم" "().

\section{التزبية الوسطية على الآداب الاجتماعية؛}

الآداب الاجتماعية في الإسـلام كثيرة ومتعددة، فهناك آداب للطعام والشراب الابعاب وآداب

للاستئذان وآداب للسلوك العام ومعاملة الآخرين.

وحين تطبق النظرية الإسلامية على الأبناء من خلال تعليمهم لهذه الآداب وتعويدهم

عليها بحيث تصبح عندهم خلقًا و سجية... فلا شك آن ذلك ييعل المجتمع كله آمنا مطمئنا،

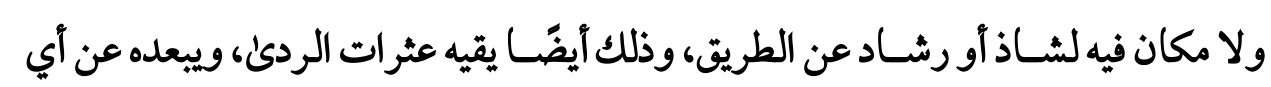

$$
\text { هزات تقوض بنيانه. }
$$

والآداب الاجتماعية في الإسـلام تكتنف حياة المسـلم كلها، وضــهـا القرآن المجيد والسنة النبوية المطهرة وهسبنا أن تعليم الأبناء هذه الآداب يمثل قمة العلاقة الإنسانية بين

$$
\text { الآباء والأولاد -وكذا المجتمع -. }
$$

الالتزام بأدب الطعام يحقق فيه الخير والبركة، ونجمل هذه الآداب فيا يأتي: 1-التسمية في أول الطعام وحمد الله في آخره.

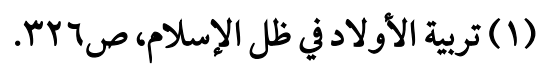

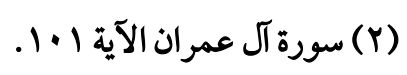


عن عائشة رضى الله عنها قالت: قال رسول الله - إس - "إذا أكل أحدكم فليذكر اسم الله

$$
\text { تعالئ. فإن نسئ فليقل بسم الله في أوله وآخره" }
$$

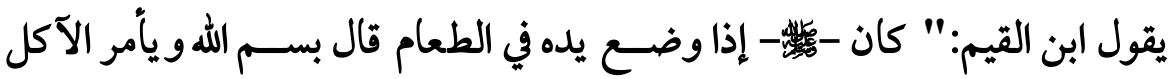

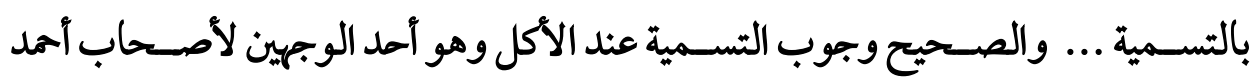
وأحاديث الأمر بها صحيحة صريية، ولا معارض لها ولا إجماع يسوغ غخالفتها ويخرجها عن ظاهرها، وتاركها شريك الشيطان في طعامه وشرابه" ().. وهذه التسمية تغلق كل منفذللشيطان ياتّي منه أثناء الأكل، فمن الثابت أن الإنسان إذا ترك التسمية شاركه الشيطان في أكله ونزعت منه البركة فإنه يستحل الأكل الذي لميذكر اسم الله عليه، وأكل الشيطان محمول علن حقيقته كما يقول الشوكاني: "والذي عليه الجمهور من السـلف والخلف من المحدثين وغيرهم آن أكل الثـيطان محمول على ظاهره، وأن للشيطان يدين ورجلين، وفيهم ذكر وأنثى، وأنه يأكل حقيقة بيده إذا

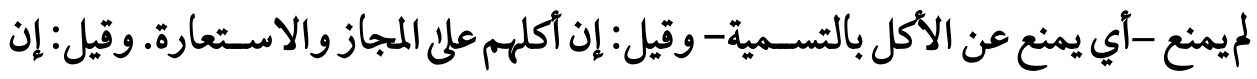

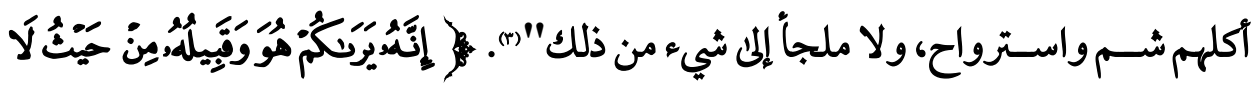
(s) وأنا مع الثـــ كاني فيـا ذهب إليه من أكل الثــــان علن الحقيقة، فمن الثابت أن الشيطان يرئ الإنسان -بكل تصرفاته- ولا يراه الإنسان، ويأكل ويشرب كالإنسان تماما،

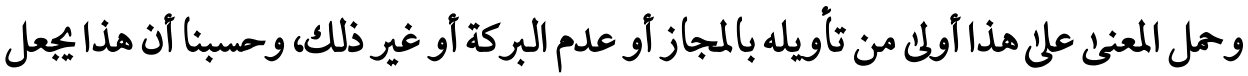
الإنسان أكثر تذكرًا ولا ينسئ التسمية.

$$
\begin{aligned}
& \text { (1) رواه أبو داود والترمذي. } \\
& \text { (Y) زاد المعاد، جr، ص.r.r. } \\
& \text { (Y) نيل الأوطار، ج^، ص. •17. } \\
& \text { (ع) سورة الأعراف الآية }
\end{aligned}
$$




\section{r-الاكل باليمين ومما أمامه ؛}

والأصل في هذا الأدب ما جاء في الصحيح عن عمر بن أبي سلمة قال كنت غلامًا في

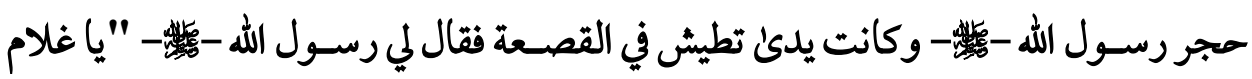
سم الله وكل بيمينك وكل مما يليك. فما زالت تلك طعمتي بعد" "(1).

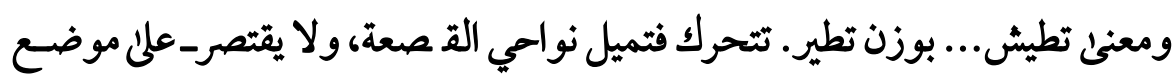
واحد" (i)

وكان من هدئ الرسول الكريم أنه يحب التيامن في كل شيء، عن عائشة رضى اللهعنا

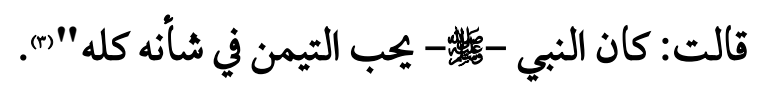
r-ومن الآداب ألا يعيب الطعام ولا يأكل متكئا.

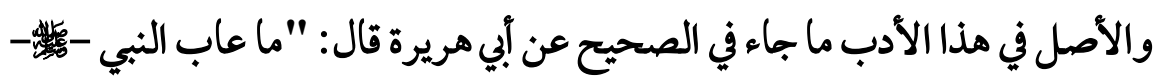
طعامًا قط إن اشتهاه أكله وإن كرهه تركه" إن الطعام نعمة من الله تعالثى أ سداه لعباده، وخليق بالإنسان أن يقابل النعمة بالشكره،

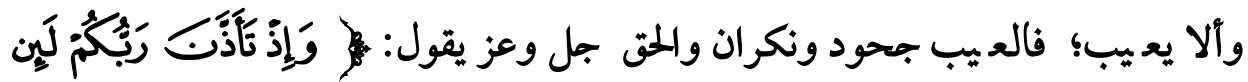

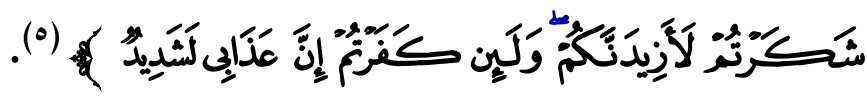

(1) رواه البخاري في كتاب الأطعمة. باب التسمية علن الطعام والكل باليمين، ج (1)، ص (0 ع، ـ0 ع.

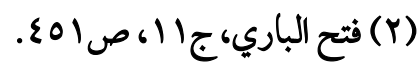

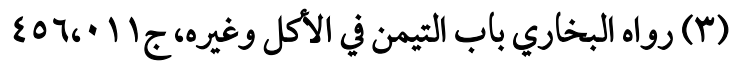

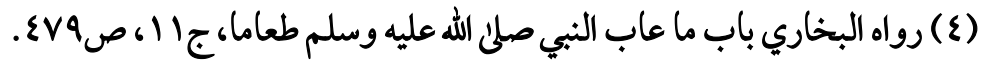

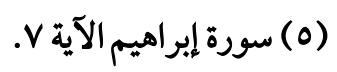


وخير للإنسان أن يتبع في هذا لا أن يزدري ما يقدم له من مأكل، فهذا الصنيع يعرض النعمة للزوال؛ فإن مالت نفسه إلى الطعام وقبلته أكله، وإن أبت تركه ولميعبه.

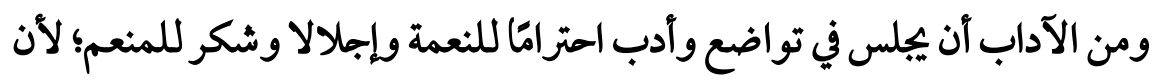
الاتكاء آثناء الطعام يوحي بالتكبر، وقد قال -عليه الصلاة والسلام - "إني لا متكتًا" "(1).

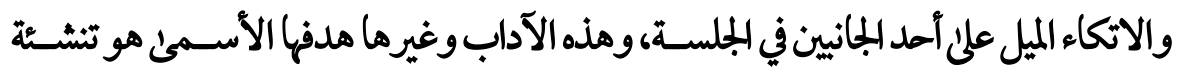
الأبناء على التريية الإسلامية الصحيحة... فضلاً عن أنها التزام يثاب عليه فاعله من اللهتعالئ الأعلائ. ثم آداب أخرئ وضحتها السنة المطهرة منها.

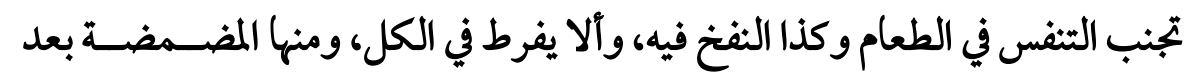

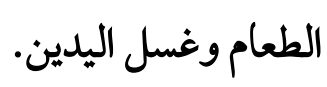

\section{ع-أدب الاستثلدان.}

لقد اهتم الإ سلامبكل قضايا الإذسان في حياته الاجتماعية، وو ضع لكل قضية الأ سس

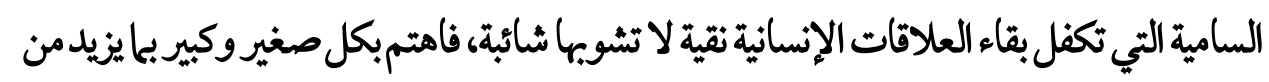
الترابط، ويوجدأسـباب التراحمو التآلف يين أبناء المجتمع. ولقديين المق سـبحانه في كتابه الكريم أسـلوب المعاملة مع الأهل ومع الناس ونظم آداب دخول الييوت، وكذاطريقة الاســئذان داخل البيت الواحد، وكل هذا الاهتحام دليل على رمة اللهبعباده. وأدب الا ستذان من الآداب الاجتحاعية التي لما أهميتها، ومع ذلك تلا شئ هذا الأدب الرفيع في دنيا الناس الآن، وغاب عن الكثيرين، وأصـبحت البيوت كلا مباحًا لكل صـغير وكبير يدخلها متخل تشـاء -فاضـمحلت الأخلاق وفســت، بسـبب الإهمال وعدم الالتزام بهذه الآداب الإلمية السامية، التي تبقى على المسلم عفته وحياء. 


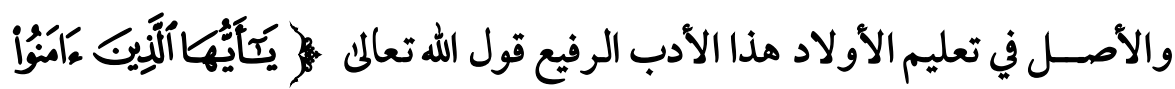

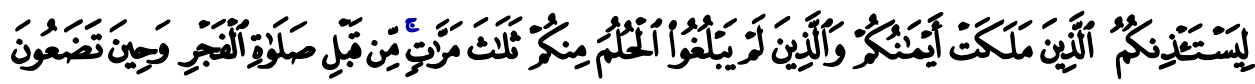

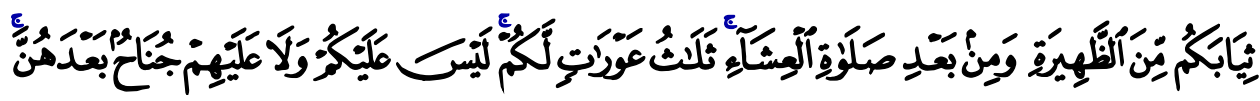

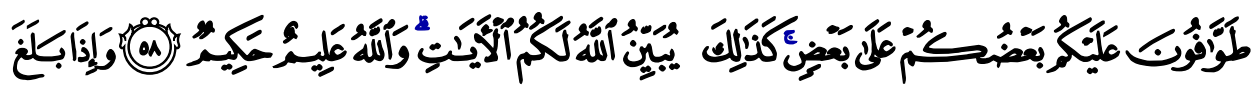

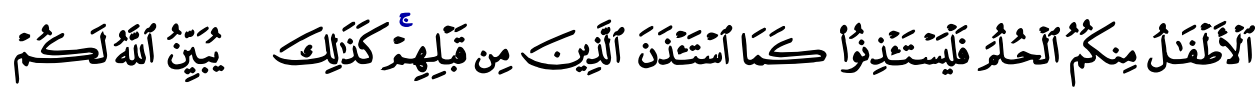

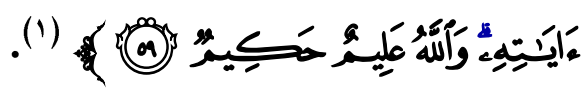

تبين الآية الكريمة للمريين كيف يعلمون أولادهم هذا الأدب، وكيف يســأذأنون في

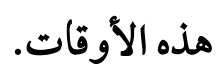

فهؤلاء الصغار الذين لميبلغوا لهم حق الاستئذان في أوقات ثلاثة.

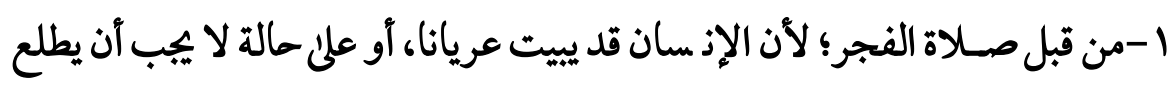
عليه فيها آحدد من الناس. r-وقت القيلولة لأن الإنسان قد يضع ثيابه في تلك الحالة ويستريح.

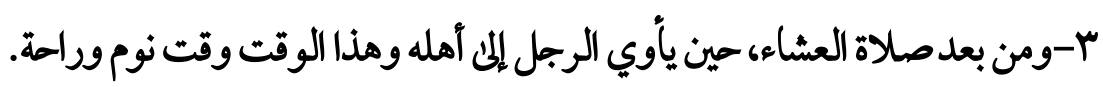

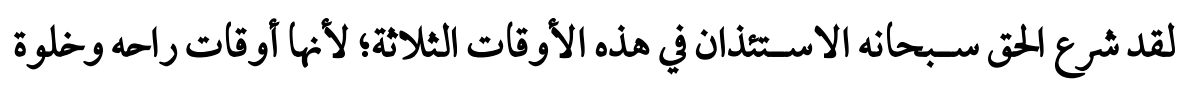
بين الرجل وزوجه، وهي حالة لا ييب أن يراه الأولاد الصغار أو يطلعوا علن والديهم في مثل هذه الحالة. ألا ما أعظم هذا التشريع الذي يحافظ على الشـعور الإنساني، وما آجمل الالتزام به... فإذا بلغ الصغار سن البلوغ فقدوجب عليهم آن يستأذنوا في هذه الأوقات وفي غيرها وهذا

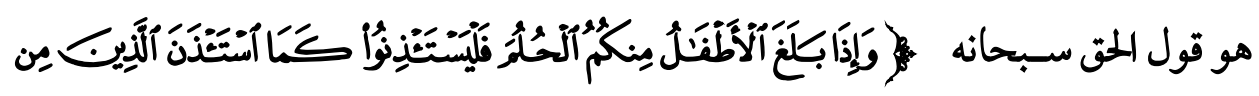

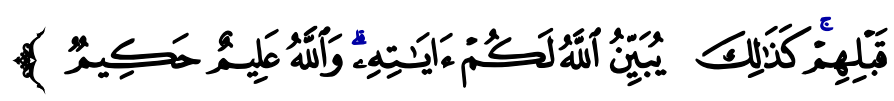




\section{سبب نزول الآية؛}

"قال ابن عباس: وجه رسـول اللهصـلني الله عليه وسـلم غلاما من الأنصـار يقال له مدلج بن عمرو إلى عمر بن الخطاب رضي الله عنه وقت الظهيرة؛ ليدعوه فدخل فرأئ عمر بحالة كره عمر رؤيته ذلك فقال: يا رســول اللهوددت لو أن الله تعالى أمرناو ونهانا في حال الاستئذان فأنزل الله تعاله هذه الآية. وقال مقاتل: نزلت في أسماء بنت مرثد كان لها غلام كبير فدخل عليها في وقت كرهته

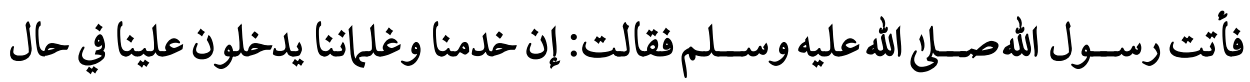
نكر هها فأنزل الله تبارك وتعالئ هذه الآية" (1).

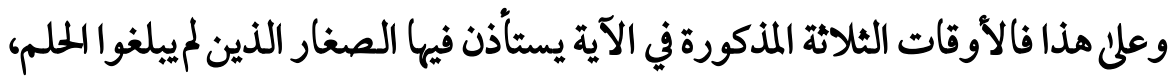
حتى إذا بلغوا سن التكليف وجب عليهم الاستئذان في مذه الأوقات وفي غيرها.

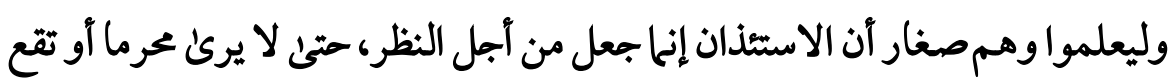

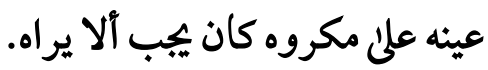
وقد قال -عليه الصلاة والسلام- إنما جعل الاستئذان من أجل البصره (").

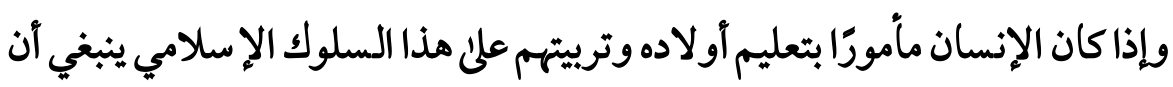
يقوم علنى الرفق والمنان، بعيدا عن الغلظة والقسوة.

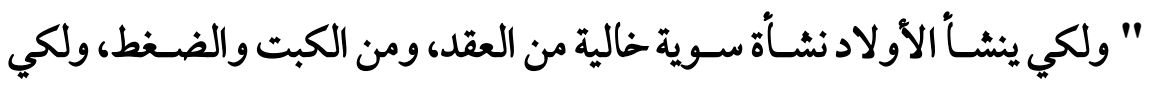
يشعروا بالرمة والسعادة والا ستقرار وهم بين آبائهم.. لكي يكونوا كذلك يحتاجون إلى آن

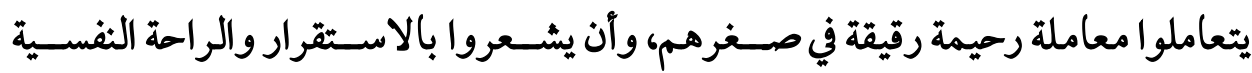
والسعادة القلبية وهم بين آبائهم وأمهاتهم، إن ذلك ييعلهم يحبون أسرهمه ويقدرون الروابط

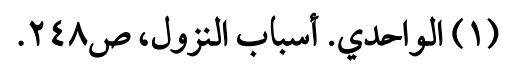

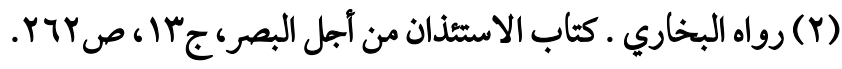


الأسرية حق قدرها، ويحاولون إقامة بجتمع -مثالي- أينا وجدوا، ولكل دور من أدوار النمو ما يناسبه" (1) - الدريه

فالولد في صغره له لون خاص من التربية، وكذا أ سلوب خاص فيها، فإذا شب وكبر

$$
\text { فله أيضًا في مذه السن أسلوب خاص. }
$$

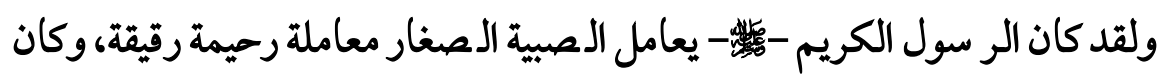

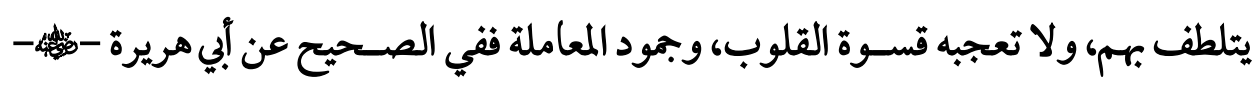

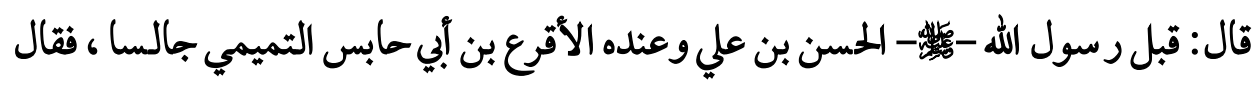

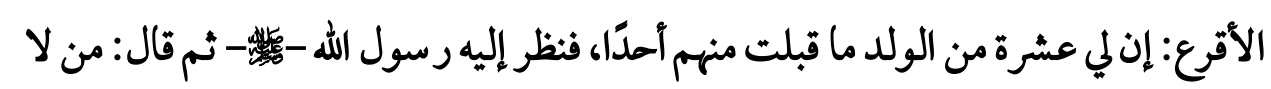

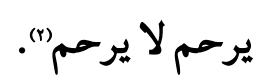

وعن البراء قال: دخلت مع أبي بكر أول ما قدم المدينة، فإذا عائشسة ابته مضسجعة قد

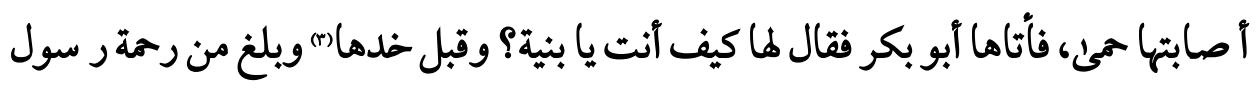

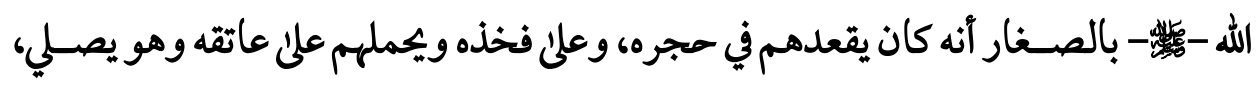
وهذا كله ثابت في صحيح السنة.

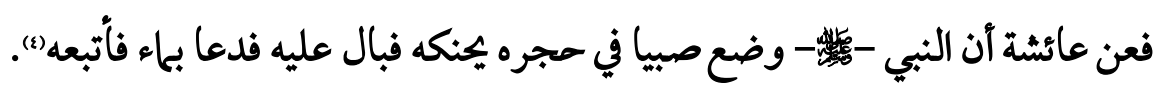

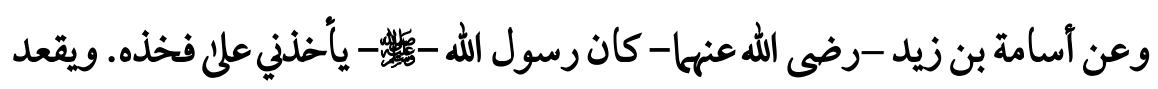

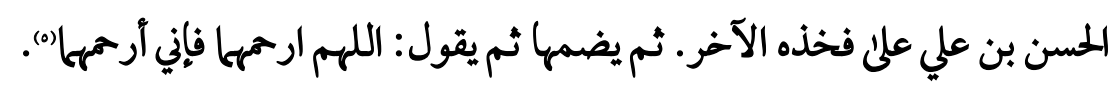

(1) السلوك الاجتاعي في الإسلام ص عابr.

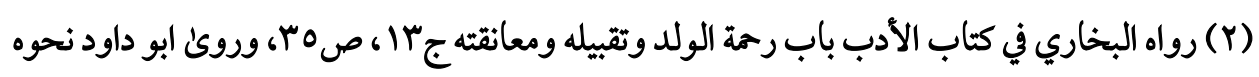

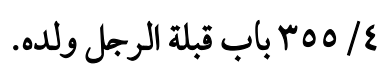

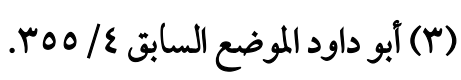

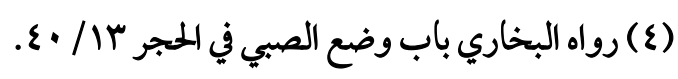
(0) رواه البخاري باب وضع الصبي على الفخذ بـ/ / (ع، عـ. 
من هذا وغيره. نتعلم الرفق بالصغار، وطيب معاملتهم، والتلطف معهم.

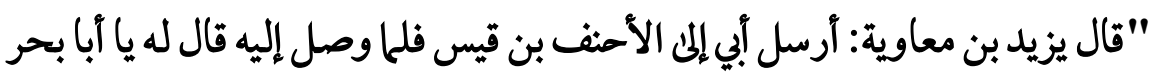
ما تقول في الولد؟ قال: يا أمير المؤمنين ثمار قلوينا، وعماد ظهورنا، ونحن لهم أرض ذليلة

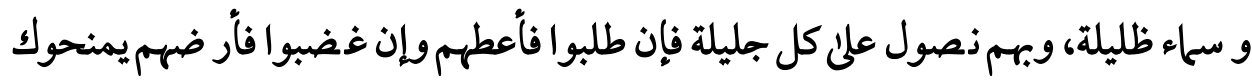
ودهم ويجبوك جهدهم ولا تكن عليهم ثقلا ثقيلا فيملوا حيا تك ويودوا و فا تك، ويكرهوا قربك، فقال له معاوية لله أنت يا أحنف لقد دخلت علي وأنا مملوء غضبا وغيظا على يزيد، فلمال خرج الأحنف من عنده رضي -معاوية- عن يز يد، وبعث إليه بائتي ألف درهم و ماثتي

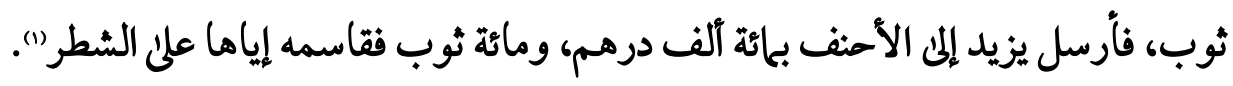

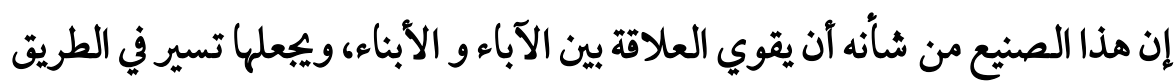
السوي. كما حث على ذلك دينتا الحنيف.

\section{حق التسويلة بين الأولاد وسطية واعتلدال؛}

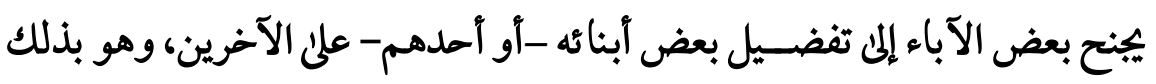
يهلك فلذة كبده من حيث لا يدري، ويضـع بذور الكراهية والبغضــاء بينهم، فضـلا عن أنه يعرض نفسه لغضب الله وعقابه.

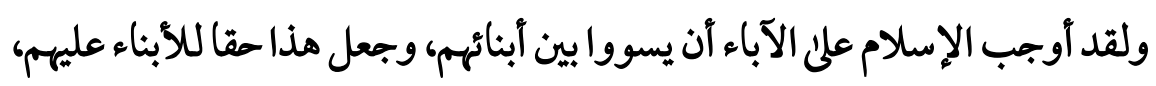

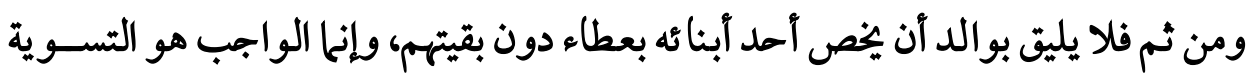

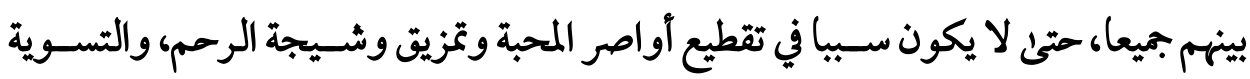
بينهم جميعا ثابته في السـنة الصسحيحة والأصـل في هذا الحق حديث النعان بن بشـير، المتفق عليه. وقد ترجم الإمام البخاري -رحمه الله- لهذا الحديث بقوله. باب المبة للوالدوإذا أعطى بنه 
ولده شيئالميز حتى يعدل بينهم ويعطي الآخر مثله ولا يشهد عليه وقال النبي بين أبنائكم.

\section{روايات العديثة}

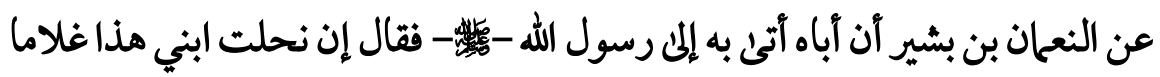
فقال: أكل ولدك نحلت مثله؟ ـ قال لا قال: فأرجعه (1). وفي رواية عن حصين عن عامر قال: سمعت النعان بن بشير -رضي اللهنها- وهو

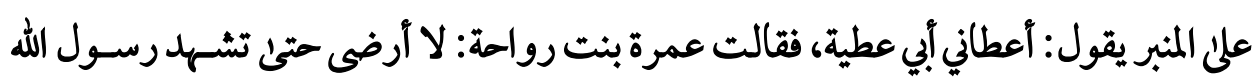
أشهك يا رسول الله قال: أعطيت سائر ولدك مثل هذا؟ قال: لا قال: فاتقوا اللهواعدلو ابين أولادكم . قال: فرجع فرد عطيتها. (1).

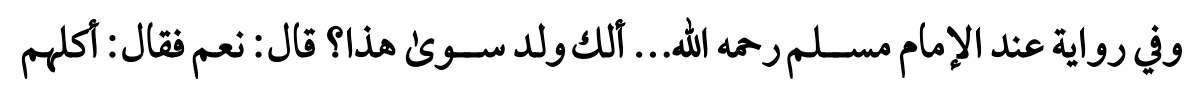

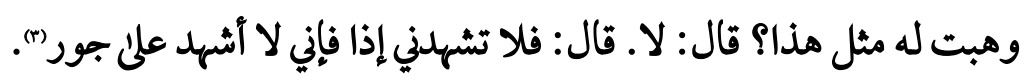

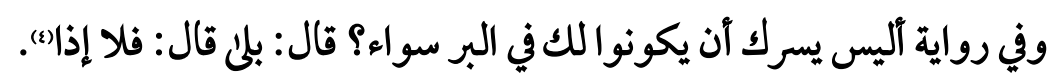

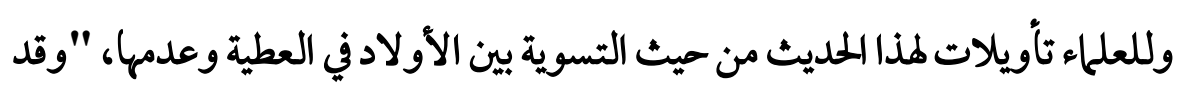

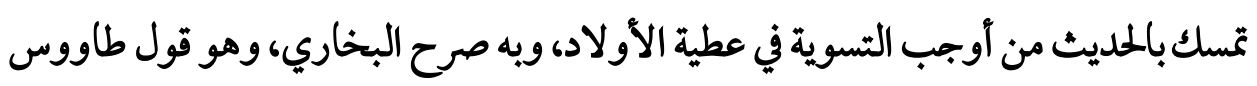

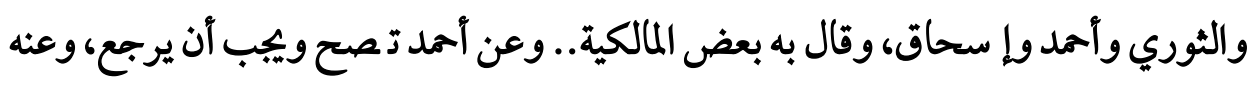

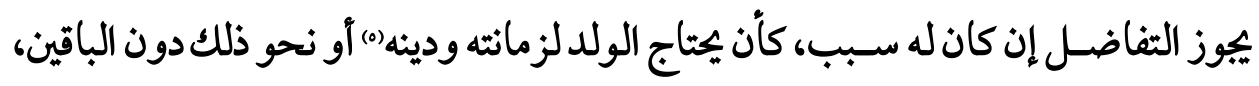

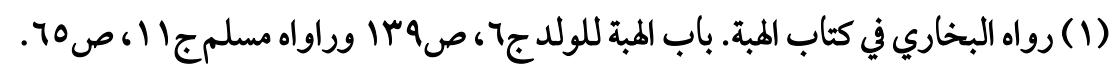

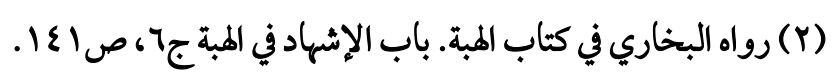

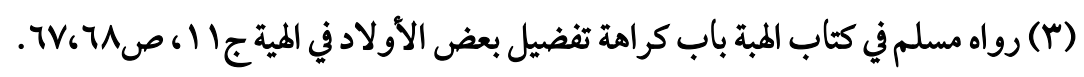

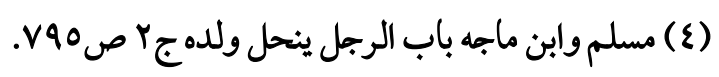

$$
\begin{aligned}
& \text { (0) أي لمرضه مرضًا مزمنا لا يرجئ برؤه. أو دين عليه. }
\end{aligned}
$$


وقال أبو يوسف يجب التسوية إن قصدصح وكره، واستحبت المبادرة إلى التسوية والرجوع،

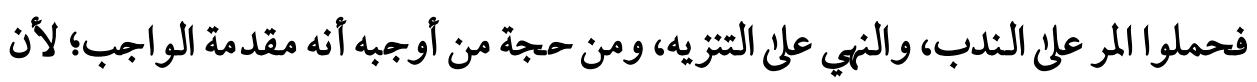
قطع الرحم والعقوق محرمان، فما يؤدي إليها يكن محرما، والتفضيل ما يؤدي إليها").

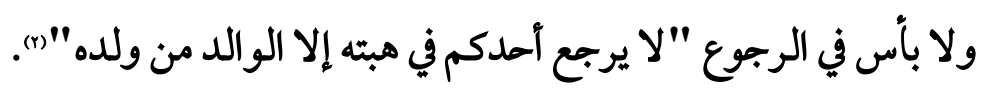

\section{تمقيب ورأي:}

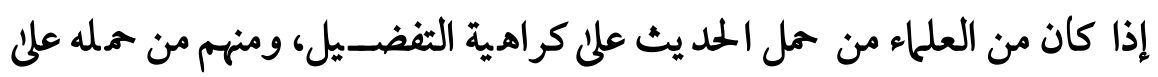

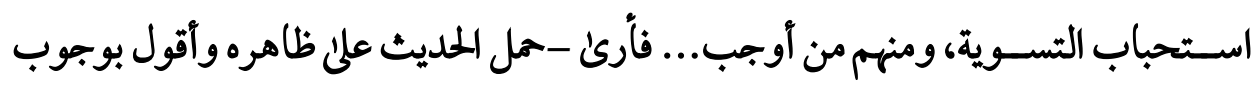

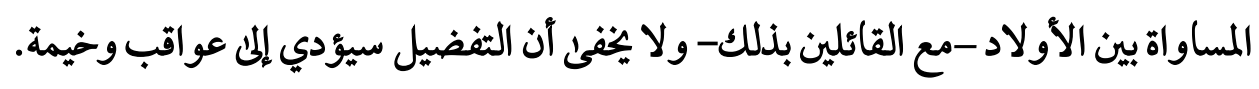

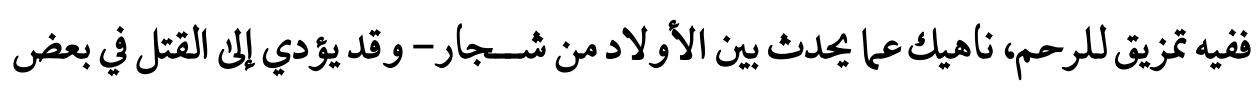

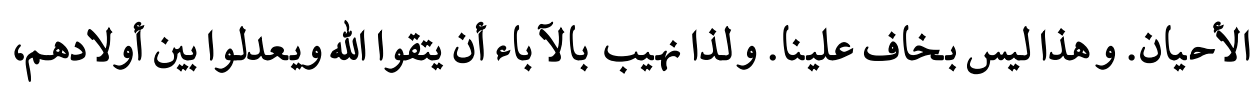

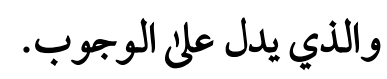
1- أن الرسول الكريم أمره بالرجوع في عطيته.

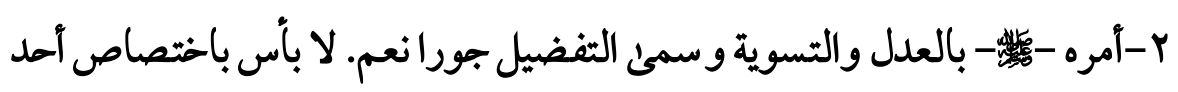
الأولاد بشي_ء لعله ظاهرة، كأن يكون مريضَــا غير قادر على الكسـب، أو وقع تحت وطأة

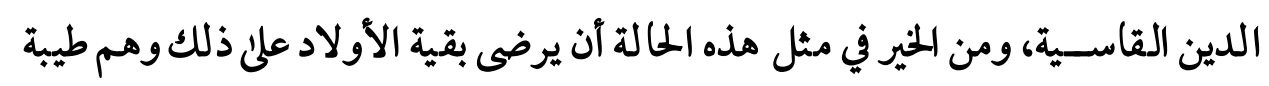
نفوسهم.

ب-أن التسوية بينهم جميعا تقوي وشائج المحبة وأوصر الأخوة. ع-كما أن الثفضيل يؤدي إلى تمزيق أواصر المحبة وإثارة الكراهية والشحناء.

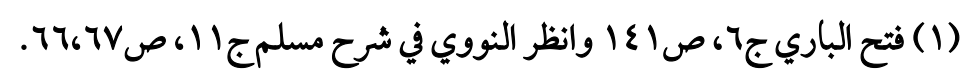

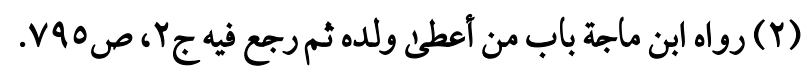


ه-معلوم أن ما يؤدي إلى الحرام فهو حرام، ولا شــك أن تفضـيل أحد الأولاد على بقية

الإخوة يؤدي إلى:

قطيعة الرحموالكراهية -وقد تتوارث- في الأجيال المتعاقبة وهذا مكمن علنم النطر.

$$
\text { وعلئ هذا!! أقول بوجوب المساواة بين الجميع. }
$$

بهذا المنجج الوسطي الفذ في التريية نضمن بجتمعا آمنا ومعافن من كل ما يشينه.

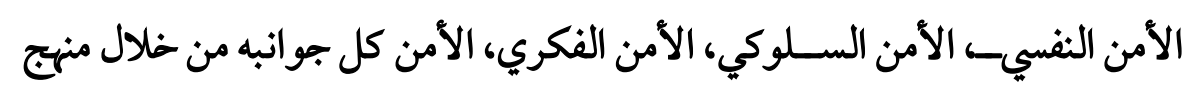

وسطي في التربية.

أ.د / هماد وهبة على جرابات 